Originalmente do Brasil e vivendo na Nova Zelândia, Tatiana Tavares ganhou diversos prêmios internacionais por sua ilustração e design em comunicação visual. Depois de uma carreira na publicidade e design gráfico, obteve o título de Mestre em Arte e Design pela AUT Univeristy em 2011. Está realizando seu doutorado practice-led pela mesma instituição, onde leciona disciplinas de ilustração, estudos narrativos e teoria do design.<ttavares@aut.ac.nz> ORCID: 0000-0002-0365-5438

Welby Ings é Professor em Design na AUT University. Possui doutorado em narratologia aplicada e foi eleito Fellow da British Royal Society of Arts. Orientou mais de 50 dissertações de mestrado e teses de doutorado. É consultor internacional para diversas organizações internacionais para assuntos de criatividade e aprendizado. Welby é ainda um multipremiado designer, cineasta e autor. Em 2002 recebeu o the New Zealand Prime Minister's award for Tertiary Teaching Excellence e, em 2013, a medalha comemorativa da AUT University por sua trajetória de pesquisa e ensino. <welby.ings@aut.ac.nz> ORCID: 0000-0002-4684-3762
Tatiana Tavares, Welby Ings*

\section{Transitando pela investigação artística em uma tese de produçäo criativa}

Resumo Este artigo considera o conceito de pesquisa artística como uma abordagem para a geração e compreensão de conhecimento. Começa com uma breve consideração do desenvolvimento histórico da investigação artística e sua relação com os processos e artefatos de pesquisa.

Em seguida, discute um projeto específico de pesquisa de doutorado, "Realidades mágicas - Uma consideração criativa das potencialidades narrativas e ilustrativas do realismo maravilhoso", como uma forma de "produção criativa". O projeto de tese, que é formatado como um livro de histórias impresso, explora os potenciais da narração polifocal e da ilustração sincrética enquanto aspectos de uma narrativa que podem ser expandidos digitalmente. Ao atuar no desenvolvimento iterativo da pesquisa, utiliza-se de um referencial metodológico que integra a investigação heurística e a prática reflexiva por meio de três métodos inter-relacionados: os diários da designer, a montagem interativa, a visão geral e teste, e o uso estratégico do feedback.

Palavras-chave Pesquisa artística, Realismo maravilhoso, Metodologia, Métodos, Polivocalidade. 


\section{Navigating artistic inquiry in a creative- production thesis: the narrative and illustrative potentials of realismo maravilhoso}

illustration and visual communication design. After leaving a career in advertising and graphic design, she received her MA in Art and Design in 2011 from AUT University. She is now completing a practice-led $\mathrm{PhD}$ at the same institution where she concurrently lectures in illustration, narrative studies and design theory. <ttavares@aut.ac.nz> ORCID: 0000-0002-0365-5438

Welby Ings is a Professor in Design at AUT University. He holds a $\mathrm{PhD}$ in applied narratology and is an elected Fellow of the British Royal Society of Arts. To date he has supervised over $50 \mathrm{PhD}$ and Master of Philosophy theses to completion. He has also been a consultant to many international organisations on issues of creativity and learning. Welby is also a multi award winning designer, filmmaker and author. In 2002 he received the New Zealand Prime Minister's award for Tertiary Teaching Excellence and in 2013, the inaugural AUT University medal for his research and teaching. <welby.ings@aut.ac.nz>

Abstract This article considers the concept of artistic research as an approach to knowledge generation and understanding. It begins with a brief consideration of the historical development of artistic inquiry and its relationship with research processes and artefacts.

It then discusses a specific artistic PhD research project, "Magical realities - A creative consideration of the narrative and illustrative potentials of realismo maravilhoso", as a form of a 'creative-production'. The thesis project, which is formatted as a printed storybook, explores the potentials of polyvocal narration and syncretic illustration when aspects of a narrative can be digitally expanded. In actioning the iterative development of the research, a methodological framework is used that integrates heuristic inquiry and reflexive practice. Enabled through this are three interrelated methods: designer's journals, iterative assembly, overviewing and testing, and the strategic use of feedback.

Keywords Artistic research, Methodology, Methods, Polyvocality, Realismo maravilhoso. 
Esse artigo emprega uma série de questões para examinar a natureza da pesquisa artística ${ }^{1}$ como uma abordagem para a geração e compreensão do conhecimento. Começa por traçar o desenvolvimento histórico da arte como pesquisa. Em seguida, discute um projeto específico de pesquisa de doutorado artístico, Realidades mágicas - uma consideração criativa das potencialidades narrativas e ilustrativas do realismo maravilhoso, como forma de "produção criativa".

\section{Primeiro, podemos começar perguntando o que é pesquisa e qual é a sua relação com a investigação artística?}

O termo pesquisa vem do francês antigo, rechercher, e significa "procurar" ou "pesquisar algo de perto". Pesquisa foi definida como "trabalho realizado para aumentar o estoque de conhecimento". ${ }^{3}$ No Guide to the Research Grant Scheme for the UK Council (Manual de Bolsas de Pesquisa para o Conselho do Reino Unido), espera-se que tal investigação seja sistemática e inclua "uma problemática ou questões que serão abordadas no decorrer da pesquisa". Espera-se que forneça o contexto e os métodos para abordar tais questões. ${ }^{4}$

Graeme Sullivan recorda que, segundo o Iluminismo, a visão da pesquisa em arte estava amplamente sujeita a um paradigma científico objetivo e confiável. O autor argumenta que "os

This article employs a series of questions to examine the nature of artistic research ${ }^{60}$ as an approach to knowledge generation and understanding. It begins by tracing the historical development of art as research. It then discusses a specific artistic PhD research project, Magical realities - A creative consideration of the narrative and illustrative potentials of realismo maravilhoso, as a form of 'creative-production'. ${ }^{61}$

First, we might begin by asking what is research and what is its relationship to artistic inquiry?

The term research comes from old French, rechercher, and means "to seek" or "to search something closely". Research has been defined as "work undertaken in order to increase the stock of knowledge."62 In the Guide to the Research Grant Scheme for the UK Council, such inquiry is expected to be systematic and to include "a series of research questions, issues or problems that will be addressed in the course of the research." In such an undertaking one is expected to provide both the context and methods for addressing the questions. ${ }^{63}$

Graeme Sullivan suggests that following the Enlightenment, the view of research in art was largely subject to an objective and reliable 
padrões de prática que surgiram durante o Iluminismo viram o cientista e o artista compartilharem um propósito comum em querer entender como o mundo funciona"." ${ }^{5}$ No início do século $\mathrm{XX}$, a visão da educação artística era amplamente baseada em habilidades manuais para aplicações profissionais, juntamente com modelos modernistas que incluíam o artista individualizado cujas práticas envolviam o desenvolvimento de habilidades manuais e uma "forte missão vocacional". ${ }^{6}$ No entanto, mais recentemente, as práticas de arte e design exigiram mudanças na educação para abranger o empreendedorismo e áreas mais amplas de "pesquisa colaborativa, interdisciplinaridade e exploração tecnológica". ${ }^{7}$

Nas últimas três décadas, isso resultou em crescentes debates sobre o papel das práticas de pesquisa nas artes criativas e sua validação institucional. ${ }^{8}$ Embora as primeiras inovações no campo fossem em grande parte derivadas do Reino Unido, avanços consideráveis também apareceram nos sistemas universitários escandinavo, canadense e australasiano. ${ }^{9}$ Christopher Frayling sugeriu que estas questões de validação não foram apenas práticas, mas também conceituais e políticas. ${ }^{10}$

Nas décadas de 1970 e 1980 surgiram córpus de pesquisa que foram descritos como "practice-based" ("baseados na prática") ou "practice-led" ("orientados para a prática"). Tais investigações realizadas por artistas, designers, escritores e artistas criaram formas distintas de classificar e conduzir pesquisas. ${ }^{11}$

scientific paradigm. He argues that "the patterns of practice that emerged during Enlightenment saw the scientist and the artist share a common purpose in wanting to understand how the world works." ${ }^{64}$ In the early 20th Century, the vision of art education was largely rooted in manual skills for professional applications, along with modernist models that included the individualised artist whose practices involved the development of hand skills and a "strong vocational mission". ${ }^{65}$ However, more recently, art and design practices have required changes in education to encompass entrepreneurship and broader areas of "collaborative inquiry, interdisciplinarity, and technological exploration."66

In the last three decades, this has resulted in increasing debates around the role of research practices in the creative arts and their institutionalised validation. ${ }^{67}$ Although early innovations in the field were largely UK-derived, considerable advances have also profiled in Scandinavian, Canadian and Australasian university systems. ${ }^{68}$ Christopher Frayling has suggested that issues of validation have been not only practical, but also conceptual and political. ${ }^{69}$

In the 1970s and 1980s, bodies of research surfaced that were described as either "practice-based" or "practice-led." Such inquiries carried out by artists, designers, writers and performers fashioned distinctive ways 
Navigating artistic inquiry in a creative-production thesis: the narrative and illustrative potentials of realismo maravilhoso

Catherine Heard sugere que os designers que realizam pesquisas avançadas utilizando essa nova conceituação da pesquisa orientada para a prática, na época, enfrentavam um ambiente de "extrema disjunção entre o que os acadêmicos não artistas definem como pesquisa (trabalho que é mensurável, factual e baseado em resultados) e o trabalho criativo que os artistas acadêmicos e seus alunos realizaram (trabalho experimental, intuitivo e aberto). "12 Fred Schwartz observa que as práticas de estúdio de artistas acadêmicos geralmente exigiam "algum tipo de documentação, análise de esforços criativos" que ele sentia que forçavam os alunos a "traduzir esforços artísticos e criativos nos moldes e modelos de requisitos e objetivos de doutorado". ${ }^{13}$ Jillian Hamilton observa que comumente esta documentação e contextualização tomavam a forma de exegeses (teses escritas), embora estas diferissem consideravelmente em termos de estrutura e ênfase. ${ }^{14}$

\section{0 que é pesquisa artísitica?}

O centro das discussões sobre a efetividade das investigações practice-led e practice-based nas artes foi o conceito de "pesquisa artística". Julian Klein argumenta que "se 'arte' é apenas um modo de percepção, então 'pesquisa artística' deve ser o modo de um processo". ${ }^{15}$ Além disso, o autor postula que isso

of framing and conducting research. ${ }^{70}$ Catherine Heard suggests that designers undertaking advanced research degrees utilising this new conceptualisation of practice-oriented research, at the time faced an environment of "extreme disjuncture between what non-artist academics defined as research (work that is measurable, factual, and results-based), and the creative work that artist academics and their students undertook (work which is experiential, intuitive, and open-ended). ${ }^{171}$ Fred Schwartz observes that the studio practices of artist academics generally required "some kind of documentation, analysis of creative efforts" that he felt forced students "to translate artistic and creative efforts into the molds and models of doctoral requirements and objectives. ${ }^{172}$ Jillian Hamilton notes that commonly this documentation and contextualisation took the form of exegeses, although these differed considerably in structure and emphasis. ${ }^{73}$

\section{What is artistic research?}

Central to discussions about the efficacy of practice-led and practice-based inquiry in the arts was the concept of 'artistic research'. Julian Klein argues that "if 'art' is but a mode of perception, then 'artistic research' must be 
não é arte, ou seja, que isso é pesquisa, mas "pesquisa que se torna artística". ${ }^{16} \mathrm{O}$ autor sugere que a experiência artística da pesquisa pode ser encontrada em diferentes fases durante o processo de formulação da pesquisa em si. o conhecimento artístico, ele afirma, reside na equivalência entre cognição, habilidade e experiência e, como tal, pode ser considerado uma forma de "conhecimento incorporado". Klein argumenta que "o conhecimento pelo qual a pesquisa artística ambiciona, é um conhecimento sentido". ${ }^{17} \mathrm{Em}$ comparação, Henk Borgdorff sugere que a pesquisa artística é "pensamento material" ou "a articulação de conhecimento não proposicional e experiência, incorporada em obras de arte e processos criativos". ${ }^{18}$ Baseando-se nos conceitos de Martin Heidegger de "maneabilidade" ou "conhecimento prático", em que a fonte de descoberta e conhecimento reside no ato de "fazer" e na experiência sensorial (em vez de teoria) ${ }^{19}$, Barbara Bolt argumenta que " 'pesquisa' começa na prática - em nossas relações com as ferramentas e materiais de produção, ao invés de uma tentativa consciente de teorização. " 20

Diversos autores sugerem que a fabricação e o artefato podem ser considerados, em conjunto, uma forma de investigação. ${ }^{21}$ Stephen Scrivener argumenta que certos projetos de doutorado podem ser caracterizados por "identificação de problemas e solução de problemas" e estes diferem do que chama de projetos de pesquisa de "produção criativa". ${ }^{22}$ Scrivener sugere que, na

the mode of a process." ${ }^{74}$ Moreover, he posits that it is not art, that is research,

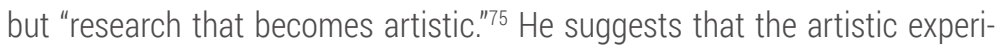
ence of research can be encountered in different phases during the process of formulating the research itself. Artistic knowledge he claims, resides in the equivalence between cognition, skill and experience and as such, it may be considered a form of "embodied knowledge". He argues that "the knowledge that artistic research strives for, is a felt knowledge."76 By comparison, Henk Borgdorff suggests that artistic research is "material thinking" or the "the articulation of non-propositional knowledge and experience, embodied in art works and creative processes. ${ }^{177}$ Drawing on Martin Heidegger's concepts of "handlability" or "praxical knowledge", wherein the source of discovery and knowledge resides in the act of 'doing' and sensorial experience (instead of in theory) ${ }_{1}^{78}$ Barbara Bolt has argued that ''research' commences in practice - in our dealings with the tools and materials of production, rather than a self-conscious attempt at theorisation." ${ }^{179}$

A number of writers have suggested that the making and the artefact may jointly be considered a form of inquiry. ${ }^{80}$ Stephen Scrivener argues that certain PhD projects may be characterised by "problem identification and problem solving" and these differ from what he calls "creative-production" research projects. ${ }^{81}$ Scrivener suggests that in creative-production the 
produção criativa, o "objeto da experiência é mais importante do que qualquer conhecimento nele incorporado". ${ }^{23} \mathrm{O}$ autor aponta que nesses projetos o pesquisador deve se comprometer com um nível de engajamento pessoal com a instabilidade. É através disso que a pesquisa navega em territórios desconhecidos e desiguais que podem levar a artefatos únicos e originais. ${ }^{24} \mathrm{Em}$ tais casos, diz Scrivener, o processo de pesquisa é emergente e pode resistir à simplificação de um único problema ou solução. Essa incapacidade de individualizar a questão de pesquisa ou a trajetória em teses orientadas para a prática também é discutida por Brad Hasemen. Este autor defende o que chama de "pesquisa performativa" ("performative research"): uma forma de investigação que raramente define problemas iniciais, mas adota "pontos de partida experienciais" para a prática. Dentro de um engajamento multifacetado e metamórfico, o autor vê realizadores assumindo a prática para ver o que emerge, e os resultados, indica o autor, podem ser "individualizados e idiossincráticos". ${ }^{25}$

\section{Qual o papel da escrita exegética em um projeto de doutorado?}

Dentro da pesquisa artística em nível de doutorado, a exegese tem servido cada vez mais para a preocupação sinalizada por Michael Biggs de que o artefato criativo "não pode colocar seu conteúdo em um contexto crítico e histórico para que pos-

"object of experience, is more important than any knowledge embodied in it." ${ }^{\prime 2}$ Scrivener suggests that in these projects the researcher must commit to a level of personal engagement with instability. It is through this that the research navigates unknown and uneven territories that can lead to unique and original artefacts. ${ }^{83}$ In such instances Scrivener says, the process of research is emergent and may resist simplification to a single problem or solution. This inability to singularise either the research question or trajectory in practice-oriented theses is also discussed by Brad Hasemen. He argues for what he calls "performative research". This is a form of investigation that rarely sets initial problems but instead adopts "experiential starting points" for practice. Within a protean engagement he sees practitioners undertaking practice to see what emerges, and the outcomes he suggests may be "individualistic and idiosyncratic." ${ }^{84}$

\section{What is the role of exegetical writing in a $\mathrm{PhD}$ project?}

Within doctoral level artistic research, increasingly the exegesis has served to address Michael Biggs' concern that the creative artefact alone "cannot place its content in a critical and historical context so that it can be demonstrated to be original and significant and therefore a contribution to 
sa ser demonstrado como original e significativo e, portanto, uma contribuição para o conhecimento". ${ }^{26}$ Stephen Scrivener argumenta que a escrita de um doutorado deve demonstrar um processo atento de "relatar [...] momentos de reflexão, incluindo consequências e respostas intencionais e não intencionais". ${ }^{27}$ Por causa do número de direções que a pesquisa orientada para a prática do doutorado pode tomar, Maarit Mäkelä enfatiza a importância de desenvolver "um plano com questões específicas e um contexto para a realização da pesquisa". ${ }^{28}$ Barbara Bolt vê a prática do estúdio e o comentário crítico formando uma "articulação dupla entre teoria e prática, em que a teoria emerge de uma prática reflexiva ao mesmo tempo em que a prática é informada". ${ }^{29}$ Tanto Jillian Hamilton quanto Welby Ings acreditam que a escrita exegética deve reconciliar a posição do pesquisador artístico entre a objetividade acadêmica isenta e a perspectiva aplicada de um realizador subjetivo. ${ }^{30}$ Elaine Thomas argumenta que, nessa tensão, os pesquisadores de doutorado que buscam investigações artísticas orientadas para a prática ainda precisam fornecer uma submissão escrita que seja "mais do que um relatório factual... deve definir alguma perspectiva crítica e intelectual e não meramente ‘justificar' a prática”. ${ }^{31}$

\section{Então, quais podem ser as características de um projeto de doutorado em pesquisa artística?}

Dado certo entendimento sobre um projeto de pesquisa artística de doutorado sendo uma prática conduzida pela reflexão e criticidade, e evidenciando alguma forma de comentário exegético, é útil voltar-se agora para o atual projeto de tese de doutorado de Tatiana Tavares, Realidades Mágicas - uma consideração criativa da potencial narrativo e ilustrativo do realismo maravilhoso. A tese compreende uma narrativa impressa ilustrada cuja história pode ser expandida através knowledge or its interpretation." ${ }^{85}$ Stephen Scrivener argues that doctoral writing must demonstrate an attentive process of "reporting [...] moments of reflection, including intended and unintended consequences and responses." 86 Because of the number of directions doctoral practice-oriented research can take, Maarit Mäkelä emphasises the importance of developing "a plan with specific research question(s) and a context for carrying out the research." ${ }^{87}$ In such reporting Barbara Bolt sees studio practice and critical commentary forming a "double articulation between theory and practice, whereby theory emerges from a reflexive practice at the same time as practice is informed by theory." ${ }^{18}$ Both Jillian Hamilton and Welby Ings believe that exegetic writing must reconcile the artistic researcher's position between disinterested academic objectivity and the invested perspective of a subjective practitioner. ${ }^{89}$ Elaine Thomas argues that within this tension, doctoral researchers pursuing practice-oriented artistic inquiries still need to provide a written submission that is "more than a factual report ... it should define some critical and intellectual perspective and it should not merely 'justify' the practice."90

\section{So, what might be the features of an artis- tic research $\mathrm{PhD}$ project?}

Practice-led doctoral artistic research projects are often driven by reflection and critical thinking. This thinking is normally made evident in some form of exegetical commentary. It is useful to turn now to Tatiana Tavares' current PhD thesis project Magical realities - $A$ creative consideration of the narrative and illustrative potentials of realismo maravilhoso. The thesis comprises an illustrated, print narrative whose story can be expanded through the use of mobile technologies. By using simple mobile devices, the user is introduced to the opinions and interpretations of three saints who relate fixed incidents in the story through distinctly different moral lenses (Fig 1). This body of practice is contextualised by a 50,000 word exegesis that positions the researcher, discusses the rationale and significance of the study, then unpacks its research design and discusses contextualising knowledge. The document concludes with an extensive critical commentary on the work. 
Navigating artistic inquiry in a creative-production thesis: the narrative and illustrative potentials of realismo maravilhoso

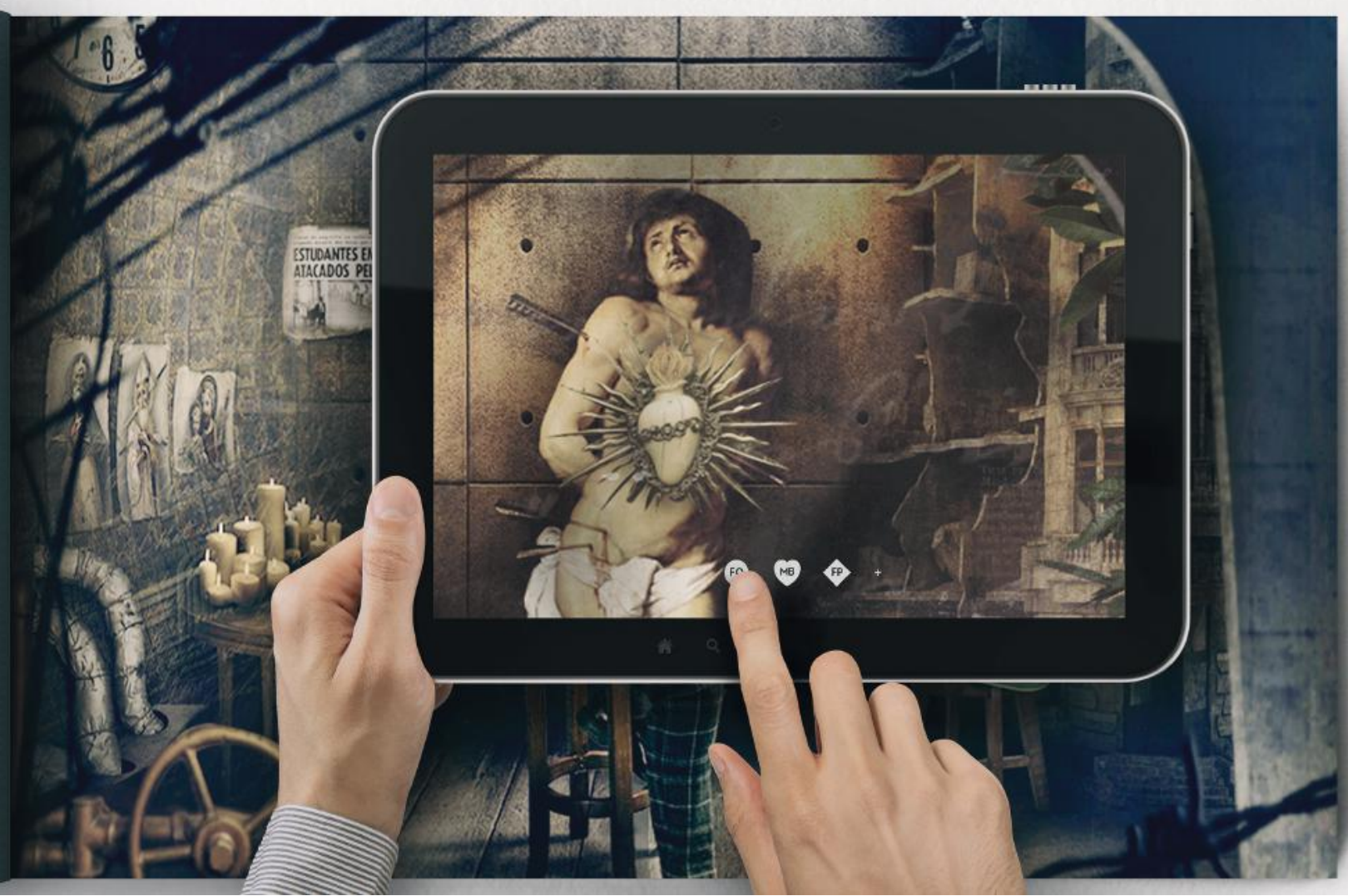

Fig 1. Página interativa do romance de realismo fantástico ilustrado.

o livro tem três santos narradores, cada um dos quais com uma versão sonora da história que é acessada por tecnologia de Realidade Aumentada (RA). Usando a imagem impressa como base, os santos distorcem as ênfases da imagem para que ela se alinhe à interpretação.

Fig 1. Interactive page from the illustrated Augmented Reality novel Saints of Paradox.

The book has three narrating saints, each of whose voiced-over rendition of the story is accessed through AR technology. Using the printed image as a base, the saints distort emphases in the picture to make it align with their interpretation. When the illustrated printed pages are scanned, the user has a the option of selecting one of 3 separate buttons, each activating a different narration. Each discrete Saint has a unique monologue, soundscape and animated intrusions that play out over the printed picture. 
do uso de dispositivos móveis (Fig. 1). Usando essa tecnologia, o leitor pode introduzir na história as opiniões e interpretações de três santos que relatam incidentes por meio de lentes morais distintas. Este corpo de prática é contextualizado por uma exegese (tese escrita) de 50.000 palavras que posiciona o pesquisador, discute a razão e o significado do estudo, para então descompactar seu desenho de pesquisa e discutir o conhecimento contextualizado. O documento é concluído com um extenso comentário crítico sobre o trabalho.

A narrativa básica da história diz respeito a uma mulher que depois de 40 anos de luto pela perda de seu amor no golpe militar de 1964 no Brasil, vive em uma sala de memórias acumuladas. Um dia, quando a única fotografia de seu amor se quebra, uma série de estranhos eventos se sucede.

Conceitualmente, o projeto de pesquisa dialoga com a narrativa e o realismo maravilhoso (uma forma distinta de realismo mágico latino-americano). Reflete também sobre certas construções socioculturais que permeiam as divisões entre crença e atualidade. Enquanto gênero subversivo, o realismo mágico é considerado dentro de uma estrutura pós-colonial e decolonial. ${ }^{32}$ No desenvolvimento das ilustrações, a pesquisadora desenha o sincretismo ${ }^{33}$ e a fotomontagem na relacionalidade artística e explora tanto a reconstituição do pré-existente quanto às tensões e mistérios ideológicos resultantes da descontextualização e da recontextualização. Os santos da história são sincréticos e as ilustrações aludem tanto às práticas cristãs tradicionais como à iconografia e às polaridades mágicas e religiosas da religião Afro-Brasileira. ${ }^{34}$

The story's baseline narrative concerns a woman who after 40 years in mourning at the loss of her lover in the 1964 Brazilian coup d'état, lives in a room of accumulated memories. One day when the only photograph of her lover breaks, it sets in train a series of strange events.

Conceptually, the research project is concerned with storytelling and realismo maravilhoso (a distinctive form of Latin American magical realism). ${ }^{91}$ It also reflects on certain socio-cultural constructs that permeate divisions between belief and actuality. As a subversive genre, magical realism is considered within a postcolonial and decolonial framework. ${ }^{92}$ In the development of the illustrations, the researcher draws syncretism ${ }^{93}$ and photomontage into artistic relationality and explores both the reconstitution of what pre-existed, and ideological tensions and mysteries resulting from decontextualisation and recontextualisation. The saints in the story are syncretic and the illustrations allude to both traditional Christian practices and iconography and magical and religious polarities of Afro-Brazilian religion. ${ }^{94}$

Storytelling in the thesis explores the potentials of polyvoca ${ }^{95}$ and dialogist narration, ${ }^{96}$ and allows the reading of different versions of a tale told by three distinctive narrators (the saints) (Fig 2). 
Navigating artistic inquiry in a creative-production thesis: the narrative and illustrative potentials of realismo maravilhoso

Contar histórias na tese explora as potencialidades da narração polivalente ${ }^{35}$ e dialogista ${ }^{36}$, e permite a leitura de diferentes versões de um conto contadas por três narradores distintos (os santos) (Fig. 2).
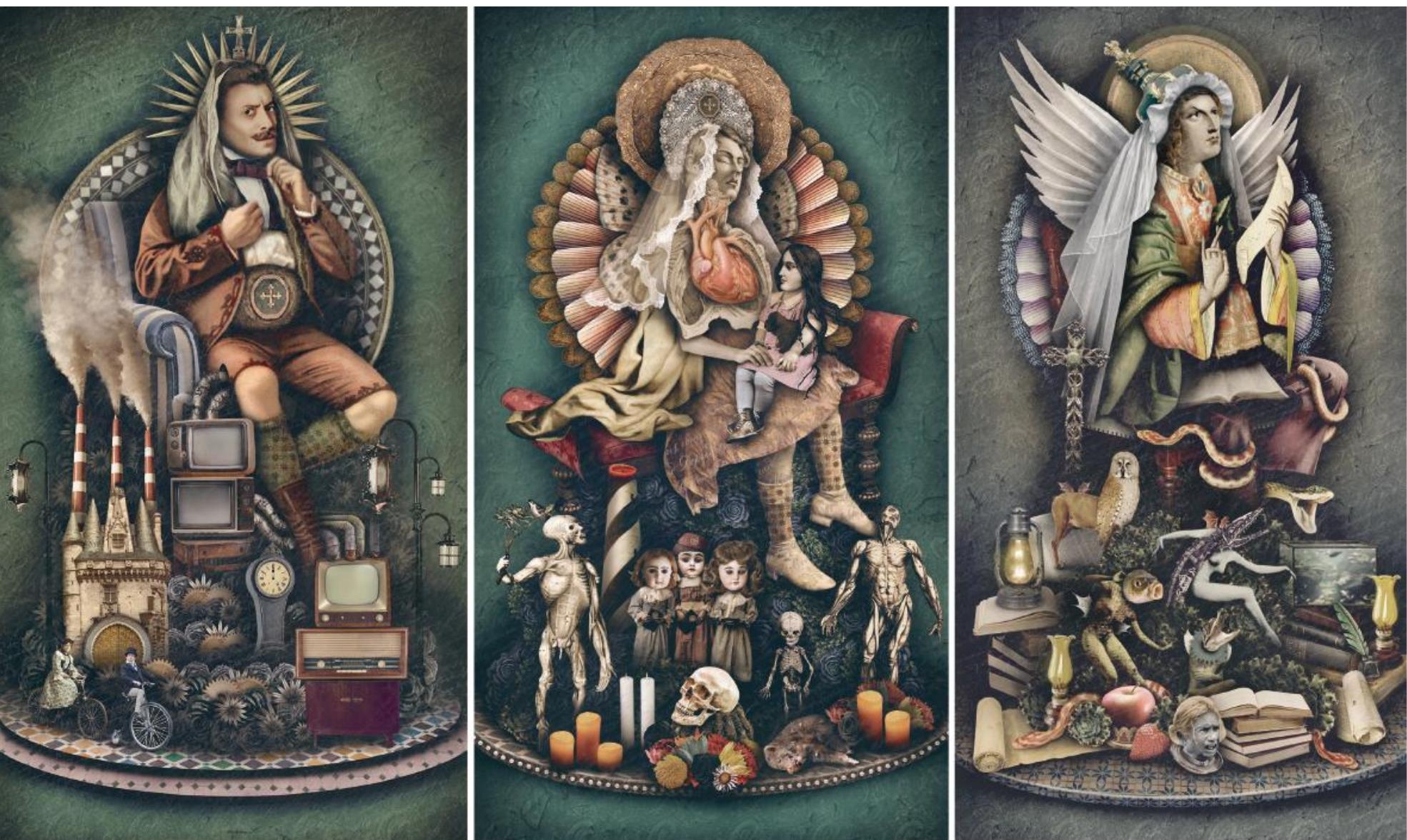

Fig 2. Ilustrações para os três santos narradores da história: o Pai do Realismo (pragmatismo), a Mãe da Compaixão (humanidade) e o Pai da Ortodoxia (julgamento justo). Cada santo interpreta eventos na história através de uma lente teológica diferente.
Fig 2. Working illustrations for the three saint narrators of the story: the Father of Realism (pragmatism), the Mother of Compassion (humanity) and the Father of Orthodoxy (righteous judgement).

Each saint interprets events in the story through a distinctively different theological lens. 


\section{Como esse tipo de projeto pode se desenvolver?}

No estudo, as questões de pesquisa foram inicialmente exploratórias e reflexivas, e serviram para criar um diálogo interno entre a realizadora e o fazer. ${ }^{37}$ Nesse sentido, o sistema de investigação empregou uma abordagem heurística com métodos distintos utilizados em sua explicação. A heurística pode ser descrita como um método informal de solução de problemas que se refere à descoberta e ao conhecimento adquirido pela experiência. Diversos autores observam que dentro de investigações heurísticas, o pesquisador às vezes tem dúvidas sobre a direção em que ela está se deslocando. ${ }^{38}$ Uma abordagem heurística foi empregada por causa de sua flexibilidade e abertura para mudanças no foco de uma questão de pesquisa. Embora muitas vezes instável, a investigação heurística está amplamente preocupada com altos níveis de exploração e descoberta, exumação, reconstituição e criação de conhecimento. ${ }^{39}$

Como forma de investigação, o projeto apoiou a aplicação de níveis sofisticados de conhecimento intuitivo e saber tácito. ${ }^{40}$ Clark Moustakas descreve esse conhecimento como uma:

... estrutura profunda que contém as percepções, sentimentos, intuições, crenças e julgamentos únicos abrigados no quadro interno de referência de uma pessoa. [Tal conhecimento o autor afirma,] governa o comportamento e determina como interpretamos a experiência. ${ }^{41}$

A pesquisadora recorreu a essa forma de conhecimento no desenvolvimento da estrutura e tratamento estilístico da narrativa. Certa quantidade desse conhecimento foi cultural ou profissionalmente fornecida e pode ser entendida como uma espécie de sensibilidade estética e sabedoria incorporada. Pensando em metáforas visuais deri-

\section{How might such a project develop?}

In the study, research questions were initially exploratory and reflective. They served to create an internal dialogue between the practitioner and the making. ${ }^{97}$ Accordingly, the system of inquiry employed a heuristic approach with distinct methods utilised in its explication. Heuristics may be described as an informal method of problem solving that is concerned with discovery and knowledge gained by experience. A number of writers note that within heuristic inquiries, the researcher is sometimes uncertain about the direction in which she is travelling ${ }^{98}$ Heuristics was employed because of its flexibility and openness to changes in the focus of a research question. While often unstable, heuristic inquiry is broadly concerned with high levels of exploration and discovery, exhumation, reconstitution and creation of knowledge. ${ }^{99}$

As a form of inquiry, it allowed for sophisticated levels of intuitive knowledge and tacit knowing. ${ }^{100}$ Clark Moustakas describes such knowledge as a:

\footnotetext{
... deep structure that contains the unique perceptions, feelings, intuitions, beliefs, and judgments housed in the internal frame of reference of a person. [Such knowledge he suggests,] governs behavior and determines how we interpret experience. ${ }^{101}$
}

The researcher drew upon this form of knowledge in the development of the narrative's structure and stylistic treatment. A certain amount of this knowledge was culturally or professionally resourced and it may be understood as a kind of embodied wisdom and aesthetic sensibility. By thinking in visual metaphors derived from this internal knowledge, the researcher was able to access "innumerable perceptions and awareness that were purely [her] own, without the interference of restrictions or judgments, with total disregard for conformity or congruence."102 Thus, she engaged in a process of "iconic indwelling", inside which Bruce Douglass and Clark Moustakas suggest, "one might be captivated by a particular image, sensation, or realization and pause to explore its meaning or significance more fully."103 
vadas desse conhecimento interno, a pesquisadora pôde acessar "inúmeras percepções e percepções que eram puramente próprias, sem a interferência de restrições ou julgamentos, com total desconsideração por conformidade ou congruência". ${ }^{42}$ Portanto, se engajou em um processo de "residência icônica", dentro daquilo que Bruce Douglass e Clark Moustakas afirmam: "alguém pode ser cativado por uma imagem, sensação ou realização particular e fazer uma pausa para explorar seu significado ou significação de forma mais completa". ${ }^{43}$

Nos estágios iniciais do desenvolvimento da história, a pesquisadora se envolveu emocionalmente com o mundo da possibilidade narrativa, imergindo-se em registros históricos do período e explorando suas reações emocionais e imaginativas em relação ao material. Nesse sentido, o mundo fictício da história que criou pode ser visto como uma extensão do self. Douglass e Moustakas veem a imersão no processo da pesquisa como parte integrante de uma investigação heurística e sugerem que ela "carrega o sentido de envolvimento total em um tema ou questão de pesquisa de tal forma que o mundo inteiro está centrado nela por um tempo". ${ }^{44}$ Nesse processo, a pesquisadora tentou visualizar e fazer perguntas sobre esse mundo na tentativa de fundir a ficção e a 'realidade' vivenciada. Clark Moustakas descreve essa "percepção mesclada" como uma "canção na qual o pesquisador respira vida [...] porque a questão em si é infundida no ser do pesquisador". ${ }^{45}$

Tanto Michael Polanyi quanto Welby Ings descrevem a imersão como uma forma de habitar. ${ }^{46}$ Aqui, a questão da pesquisa é absorvida pelo self e a pessoa reside no assunto ou

In the early stages of story development, the researcher engaged emotionally with the world of narrative possibility by immersing herself in historical records of the period and exploring her emotional and imaginative reactions to the material. In this regard, the fictional world of the story she created may be seen as an extension of the self. Douglass and Moustakas see immersion in the research topic as integral to a heuristic inquiry and they suggest that it "carries the sense of total involvement in a research theme or question in such way that the whole world is centered in it for a while."104 During this process, the researcher tried to visualise and ask questions about this world in an attempt to fuse fiction and experienced 'reality'. Clark Moustakas describes this 'merging perception' as a "song into which the researcher breathes life [...] because the question itself is infused in the researcher's being."105

Both Michael Polanyi and Welby Ings describe immersion as a form of indwelling. ${ }^{106}$ Here the research question is absorbed into the self and one dwells inside the issue or problem. By acting on understanding and a 
Fig 3. Estudo para a sala de estar da mulher. Para se debruçar sobre possíveis mundos fictícios de suas personagens, a pesquisadora criou fotomontagens de ambientes e situações que viu em sua mente. Ao construir tais imagens, seu pensamento tornou-se cada vez mais explícito. Mockups de imagens, como a acima, ajudou-a se aproximar consideravelmente da realização ilustrativa e narrativa do livro. problema. Ao agir sobre a compreensão e um sentimento pelo mundo ficcional que cresce, a pesquisadora pôde viver dentro de um processo de iteração e refinamento (Fig. 3). Enquanto orquestrava elementos nesse mundo, se engajou intuitivamente com a obra de arte empregando julgamento estético e estrutural. Isso permitiu que ela ganhasse um claro senso de direção. Bruce Douglass e Clark Moustakas afirmam que:

... ser vago e sem forma são características no começo, mas um senso crescente de significado e direção surge à medida que as percepções e compreensões do pesquisador crescem e os parâmetros do problema são reconhecidos. ${ }^{47}$

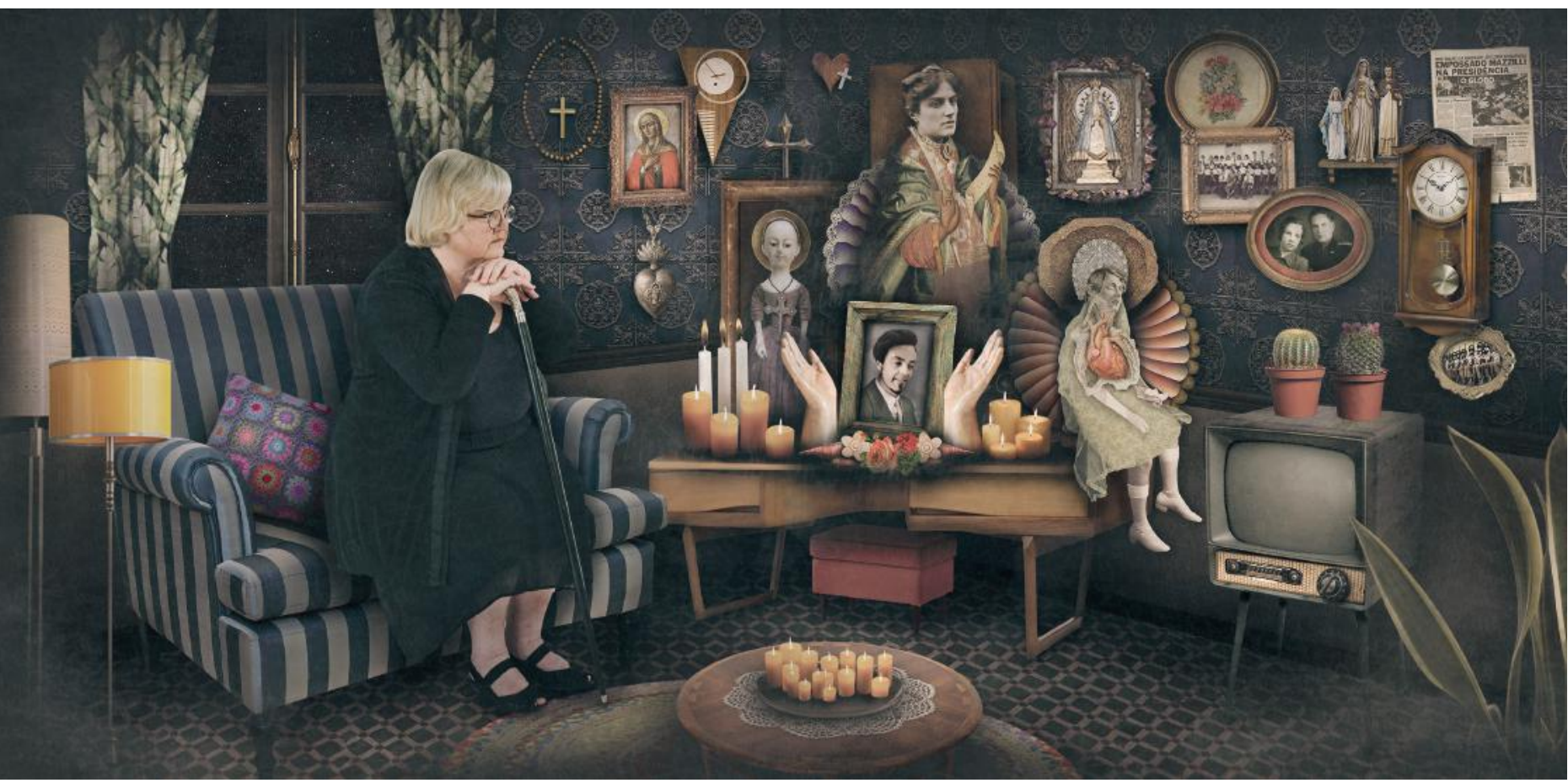

Fig 3. Study for the woman's living room.

To dwell inside possible fictional worlds of her characters the researcher created photomontages of environments and situations that she saw in her mind's eye. By constructing such images, her thinking became increasingly explicit. Mocked up images like the one above assisted her as she moved incrementally closer to the illustrative and narrative realization of the book. feeling for the fictional world as it grows, the researcher was able to live inside a process of iteration and refinement (Fig 3). As she orchestrated elements in this world, she engaged intuitively with the artwork by employing aesthetic and structural judgment. This enabled her to gain a clear sense of direction. Bruce Douglass and Clark Moustakas suggest:

\footnotetext{
... vague and formless wanderings are characteristic in the beginning, but a growing sense of meaning and direction emerges as the perceptions and understandings of the researcher grow and the parameters of the problem are recognized."107
} 
Navigating artistic inquiry in a creative-production thesis: the narrative and illustrative potentials of realismo maravilhoso

Tendo discutido a aplicação metodológica do trabalho, agora é válido considerar os métodos aplicados em testes e refinar as questões que ocorrem durante esta primeira fase da pesquisa. Devido à natureza instável da investigação heurística e suas possíveis desvantagens, esses métodos foram empregados para ajudar a pesquisadora a navegar por um equilíbrio produtivo entre pensamento interno, planejamento e produtividade externa.

\section{0 diário da designer}

A primeira fase da pesquisa envolveu duas formas de documentação; um diário digital e outro físico. Esses diários funcionavam como locais onde as relações entre os elementos poderiam ser consideradas, testadas e refletidas. Estes não eram tratados como "objeto(s) precioso(s) e autoconsciente(s), mas como dispositivo(s) interativo(s) ...", ${ }^{48}$ que possibilitavam a reflexão contínua em ação. ${ }^{49}$

o jornal digital (usando o software One Note) tornou-se um arquivo com notas de conhecimento e inspiração potencialmente relacionadas à prática. Continha referências visuais na forma de moodboards e considerações sobre o universo narrativo. Registros de entradas estavam relacionados com cor, textura emocional, representações históricas e teorias relacionadas. Artigos foram incluídos com hiperlinks para acesso contínuo a dados online. Ao tentar agrupar e sintetizar material em corpos coesivos, projetos produtivos começaram a surgir neste documento. Em investigações heurísticas, Gerhard Kleining e Harald Witt observam que, quando agrupando dados provisoriamente, os padrões que inicialmente não eram claros podem se conectar e a "estrutura geral do tópico, gradualmente, emergirá". ${ }^{50}$

O segundo diário da pesquisadora era físico (analógico). Compunha-se de um conjunto de cadernos que continham sinopses iterativas, narrativas experimentais, storyboards anotados (Fig. 4), esboços e reflexões relacionadas ao feedback sobre o pen-
Having discussed the methodological application of the work, it is now useful to clarify the methods applied in testing and refining the questions occurring during this first phase of research. Because of the unstable nature of heuristic inquiry and its potential disadvantages, these methods were employed to help the researcher to navigate a productive balance between interior thinking, planning and external productivity.

\section{Designer's Journals}

The first phase of the research involved two forms of documentation; a digital and a physical journal. These journals functioned as locations where relationships between components could be considered, tested and reflected upon. They were not treated as "precious, self-conscious object[s], but as interactive device[s] .. .108 , that enabled ongoing reflection-in-action. ${ }^{109}$

The digital journal (using OneNote software) became a notated archive of knowledge and inspirations potentially relating to the practice. It contained visual references in the form of moodboards and considerations of the story world. Entries were concerned with colour, emotional texture and historical depictions and related theory. Articles were included with hyperlinks for ongoing access to online data. By tentatively grouping and synthesising material into cohesive bodies, productive designs began to emerge in this document. In heuristic inquiries, Gerhard Kleining and Harald Witt note that when tentatively grouping data, patterns that may initially have been unclear may connect and the overall "structure of the topic, will gradually emerge."110

The researcher's second journal was physical. It comprised a set of notebooks that contained iterative synopses, experimental narratives, annotated story boards (Fig 4), sketches and reflections related to feedback on iterative thinking. Rapid sketching in this journal enabled the researcher to navigate quickly between ideas with minimal restriction. In this process she was able to rapidly clarify her thinking and open up potential new directions. This process enabled her to engage in an: 
samento iterativo. Esboços rápidos neste diário permitiram que a pesquisadora transitasse rapidamente entre ideias com restrição mínima. Neste processo, ela foi capaz de esclarecer rapidamente seu pensamento e abrir novas direções em potencial. Esse processo permitiu se envolver em uma:

... personificação do saber ainda não conhecido, na qual a intencionalidade e as competências técnicas e operacionais... interagem com conhecimento tácito, intuição e livre associação, formando um engajamento que possibilitou uma performance diante do alto risco, da instabilidade radical e do fracasso". ${ }^{51}$

À medida que a pesquisa progrediu, o material esboçado foi avançado usando processos iterativo, de fotomontagem, de montagem e de teste. embodiment of knowing yet unknowing, where intentionality and technical and operational competencies ... osmosed with tacit knowledge, intuition and free association, forming an engagement that enabled performance in the face of high risk, radical instability and failure."111

As the research progressed sketched material was advanced using a process of iterative, photomontaged, assembly and testing.

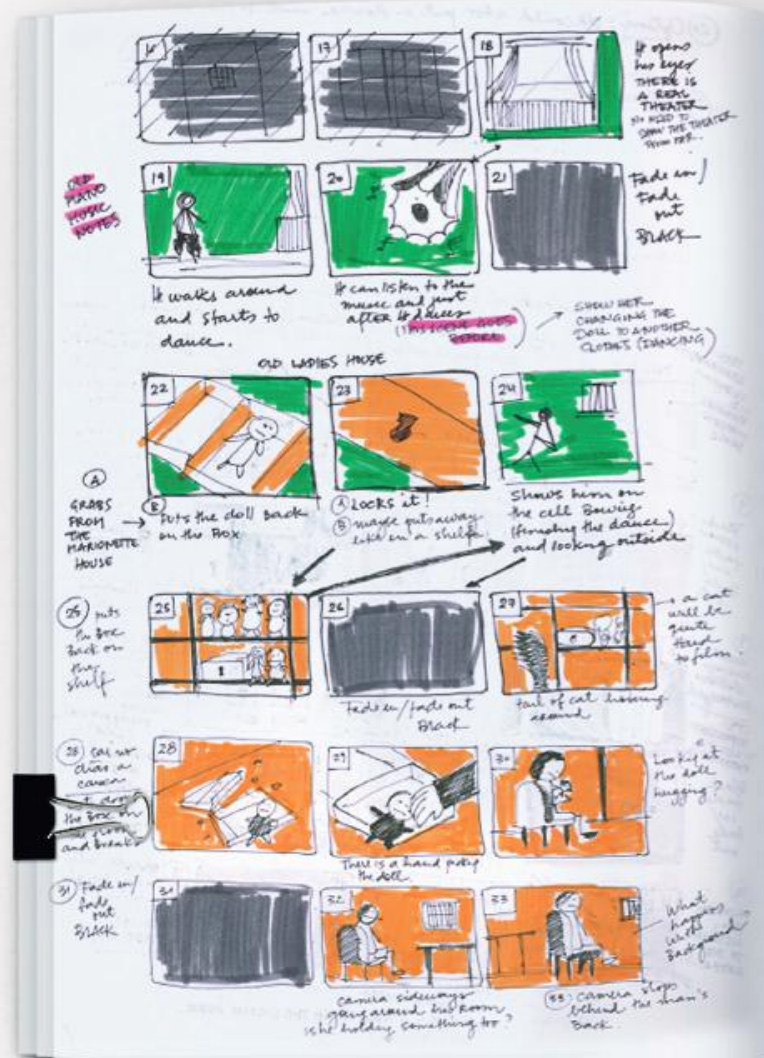

Fig 4. Página dupla distribuída a partir de um diário físico (analógico) mostrando esboços e anotações de ideias.

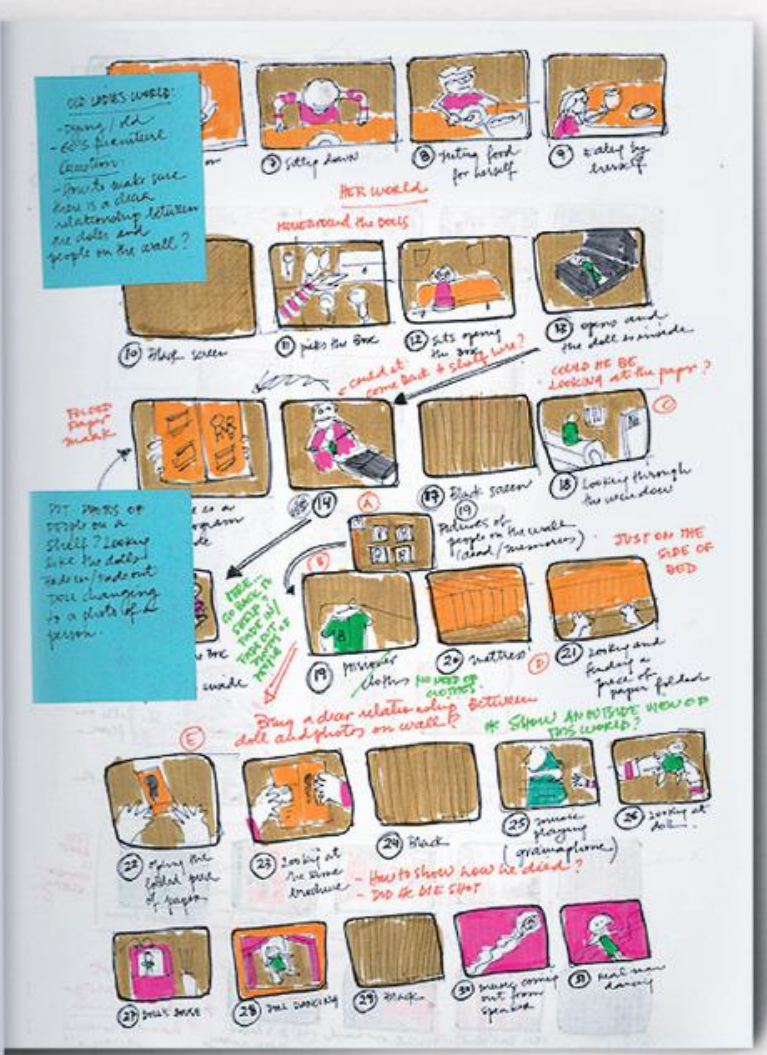

Fig 4. Double page spread from a physical journal showing ideational sketching and notes. 
Navigating artistic inquiry in a creative-production thesis: the narrative and illustrative potentials of realismo maravilhoso

\section{Montagem iterativa, visão geral e teste}

O processo de desenhar o pensamento inicial em um estilo tangível e com continuidade estrutural envolveu um engajamento reflexivo com o pensamento material. Isso tomou a forma de protótipos físicos (para formatos de livros e adereços) e de ilustrações experimentais e fotomontagens.

Os métodos utilizados nesta fase da investigação são descritos por Donald Schön como prática auto reflexiva. Aqui o realizador atua enquanto pesquisador e como tal:
... a conversa situacional é reflexiva. Em resposta à fala de fundo, o designer reflete na ação sobre a cons- trução do problema, as estratégias de ação ou sobre o modelo dos fenômenos que estiveram implícitos em seus movimentos. ${ }^{52}$

Ao desenvolver estudos ilustrativos para o universo narrativo, a pesquisadora se envolveu em um processo de "descoberta em ação", no qual dialogou entre experimentação e hipóteses. Donald Schön chama esse processo de experimentação em que o pesquisador estabelece uma ação pretendida de "teste de movimento reflexivo". 0 autor afirma que "às vezes fazemos as coisas para ver o que acontece: tomamos medidas para produzir uma mudança

\section{Iterative assembly, overviewing and testing}

The process of drawing initial thinking into tangible style and structural continuity involved a reflexive engagement with material thinking. This took the form of physical prototypes (for book formats and props), and experimental, photomontaged illustration.

The methods used in this phase of the inquiry Donald Schön describes as self-reflexive practice. Here the practitioner acts as the researcher and as such the:

\footnotetext{
... conversation with the situation is reflexive. In answer to the situation's back-talk, the designer reflects-in-action on the construction of the problem, the strategies of action, or the model of the phenomena, which have been implicit in his moves. ${ }^{112}$
}

When developing illustrative studies for the story's world, the researcher engaged in a process of 'discovery in action' where she dialogued between experimentation and hypothesis. Donald Schön calls this process of experimentation in which the researcher sets up an intended action "reflexive move-testing". He suggests that this is a process "in which we 
pretendida". Esse processo pode ser muito flexível e o pesquisador se engaja em uma forma de diálogo exploratório em que os ensaios são "realizados apenas para ver o que se segue, sem acompanhar previsões ou expectativas. Experimentação exploratória, Schön afirma, “é a atividade lúdica e exploratória pela qual sentimos as coisas. É bem sucedida quando leva à descoberta de algo lá". ${ }^{53}$

No projeto de tese, a designer reuniu iterativamente ilustrações rascunhadas e nítidas no Photoshop, nas quais os potenciais eram orquestrados, mas permaneciam ajustáveis. Muitas vezes, essas ilustrações exploratórias continham até 50 camadas (layers). Nessas construções, a pesquisadora acrescentou, subtraiu ou alterou proporções e relações em um quadro multifacetado de possibilidades (Fig. 5). Tais movimentos, Schön diz, produzem "mudanças não intencionais que dão novas situações aos significados. A situação fala de volta, a realizadora escuta, e enquanto ela aprecia o que ouve, reformula a situação mais uma vez". ${ }^{54}$

sometimes do things in order to see what happens: we take action in order to produce an intended change."113 This process can be very flexible and the researcher engages in a form of exploratory dialogue. Here trials are "undertaken only to see what follows, without accompanying predictions or expectations."114 Exploratory experimentation Schön suggests "is the probing, playful activity by which we get a feel for things. It succeeds when it leads to the discovery of something there."115

In the thesis project the designer iteratively assembled rough, clearcut illustrations in Photoshop. Here potentials were orchestrated but remained adjustable. Often these exploratory illustrations might contain up to 100 layers at a given time. In these constructions the researcher added, subtracted or altered proportions and relations on a protean canvas of possibility (Fig 5). Such moves Schön suggests produce "unintended changes which give the situations new meanings. The situation talks back, the practitioner listens" and as she appreciates what she hears, she reframes the situation once again. ${ }^{116}$ 
Navigating artistic inquiry in a creative-production thesis: the narrative and illustrative potentials of realismo maravilhoso
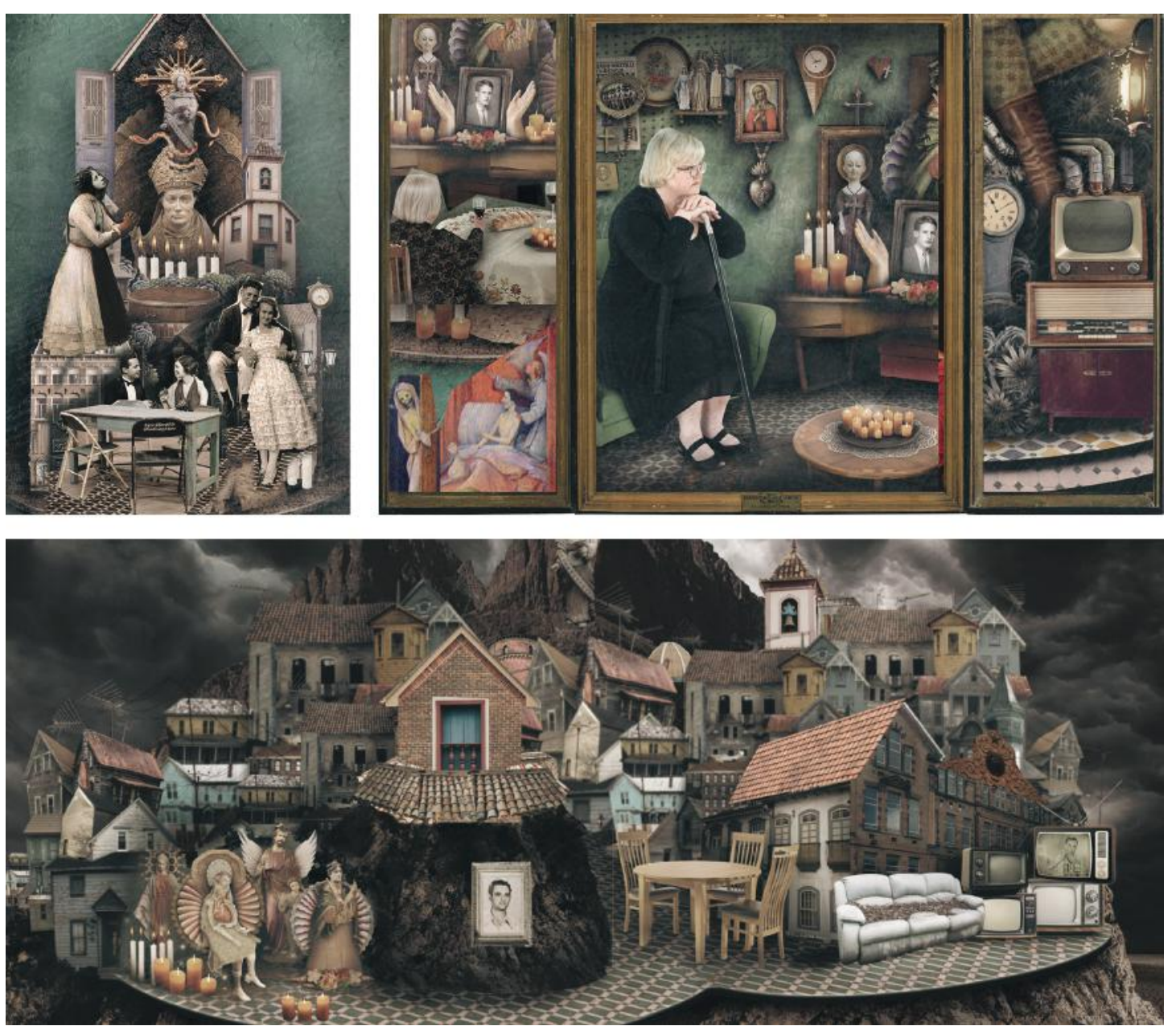

Fig 5. Teste iterativo de potenciais tratamentos de ilustração. Esses experimentos mostram uma seleção de ensaios composicionais em que os arranjos de personagens e ambientes estavam sendo considerados. Da esquerda para a direita: criação de ícones religiosos consagrados (canto superior esquerdo), arranjos de tríptico (canto superior direito) e pintura narrativa (parte inferior).

Fig 5. Iterative testing of potential illustration treatments.

These experiments show a selection of compositional trials where arrangements of characters and environments were under consideration. From left to right: creation of enshrined religious icons (top left), triptych arrangements (top right) and narrative painting (bottom). 


\section{Uso estratégico do feedback}

As interfaces com esses processos relativamente internos de pensamento têm sido mais externalizadas em abordagens voltadas para a crítica e a síntese. Tanto Carole Gray quanto Welby Ings enfatizam a importância de acessar um feedback externo criteriosos ao desenvolver textos artísticos enquanto pesquisa. Welby Ings argumenta que, "sem alguma forma de feedback externo, processos puramente auto referenciados podem resultar em projetos que não exploram uma grande variedade de opções disponíveis ou que ficam aquém de seu potencial comunicativo". ${ }^{55}$

Portanto, embora certas sínteses no trabalho tenham sido processadas internamente, a pesquisadora também buscou feedbacks externos. Para manter a voz idiossincrática em seu trabalho, ela filtrou esses feedbacks, concentrando-o em utilizar perguntas relacionadas à clareza e interpretação narrativa. Isso porque, como Sandy Sela-Smith e Welby Ings, observam:

... um designer que utiliza feedback externo em uma pesquisa heurística precisa estar atento. ... A menos que o feedback seja trazido de volta para o self (em vez de simplesmente ser aplicado ao design emergente), a investigação pode ficar desconectada. 0 poder da busca subjetiva pode mudar para uma análise objetiva dos fenômenos criados. Isso pode resultar em um trabalho nos estágios finais de sua realização, perdendo muito de sua integridade e "voz" idiossincrática. ${ }^{56}$

Neste estudo da tese, a pesquisadora circulou entre a crítica interna e o feedback externo. Na primeira fase, utilizou a visualização como forma de visão narrativa e estilística e, posteriormente, lançou mão de críticas formais do trabalho em desenvolvimento.

\section{Strategic use of feedback}

Interfacing with these relatively internal processes of thinking have been more externalised approaches to critique and synthesis. Both Carole Gray and Welby Ings stress the importance of accessing insightful external feedback when developing artistic texts as research. ${ }^{117}$ Welby Ings argues that, "without some form of external feedback, purely self-referenced processes can result in designs that fail to explore a wealth of available options or fall short of their communicative potential."118

Therefore, although certain syntheses in work were processed internally, the researcher also sought feedback from external parties. To maintain the idiosyncratic voice in her work, she filtered this feedback by focusing it using framed questions relating to narrative clarity and interpretation. This is because, as both Sandy Sela-Smith ${ }^{119}$ and Welby Ings note:

... a designer employing external feedback in a heu-
ristic inquiry needs to be vigilant. ... Unless feedback
is drawn back into the self (as opposed to simply
being applied to the emerging design) the system of
inquiry can become disconnected. The power of the
subjective search can shift to an objective analysis of
the created phenomena. This can result in a work in
the final stages of its realisation, losing much of its
integrity and idiosyncratic 'voice'. ${ }^{120}$

In this thesis study the researcher moved between internal critique and external feedback. In the former phase she employed visualisation as a form of narrative and stylistic overview and in the later she utilised formal critiques of work in progress. 
Navigating artistic inquiry in a creative-production thesis: the narrative and illustrative potentials of realismo maravilhoso

\section{Visualização enquanto visão geral (overview)}

Por causa da complexidade envolvida no design narrativo e nas três interpretações polivocais, a pesquisadora usou o recurso de mostrar toda a narrativa por meio de ilustrações dispostas em uma parede (Fig. 6). As imagens representavam os principais pontos da trama da história e, quando reunidas em sua totalidade, o processo de visão geral permitia que ela considerasse esquematicamente os arcos narrativos, as transições e as descontinuidades da história. Ao considerar o livro visualmente como uma narrativa sequencial, ela foi capaz de realinhar facilmente cenas e escrever notas de alteração para si mesma. Embora a visão geral forneça inicialmente uma forma de diálogo entre a história e o self, à medida que o projeto se desenvolveu, a pesquisadora trouxe autores, ilustradores, designers e narratologistas para oferecer feedback sobre a clareza, a ênfase e o potencial narrativo do trabalho. Este método mitigou contra o desenho tornando-se excessivamente auto referencial e, consequentemente, perdendo sua eficácia comunicativa.

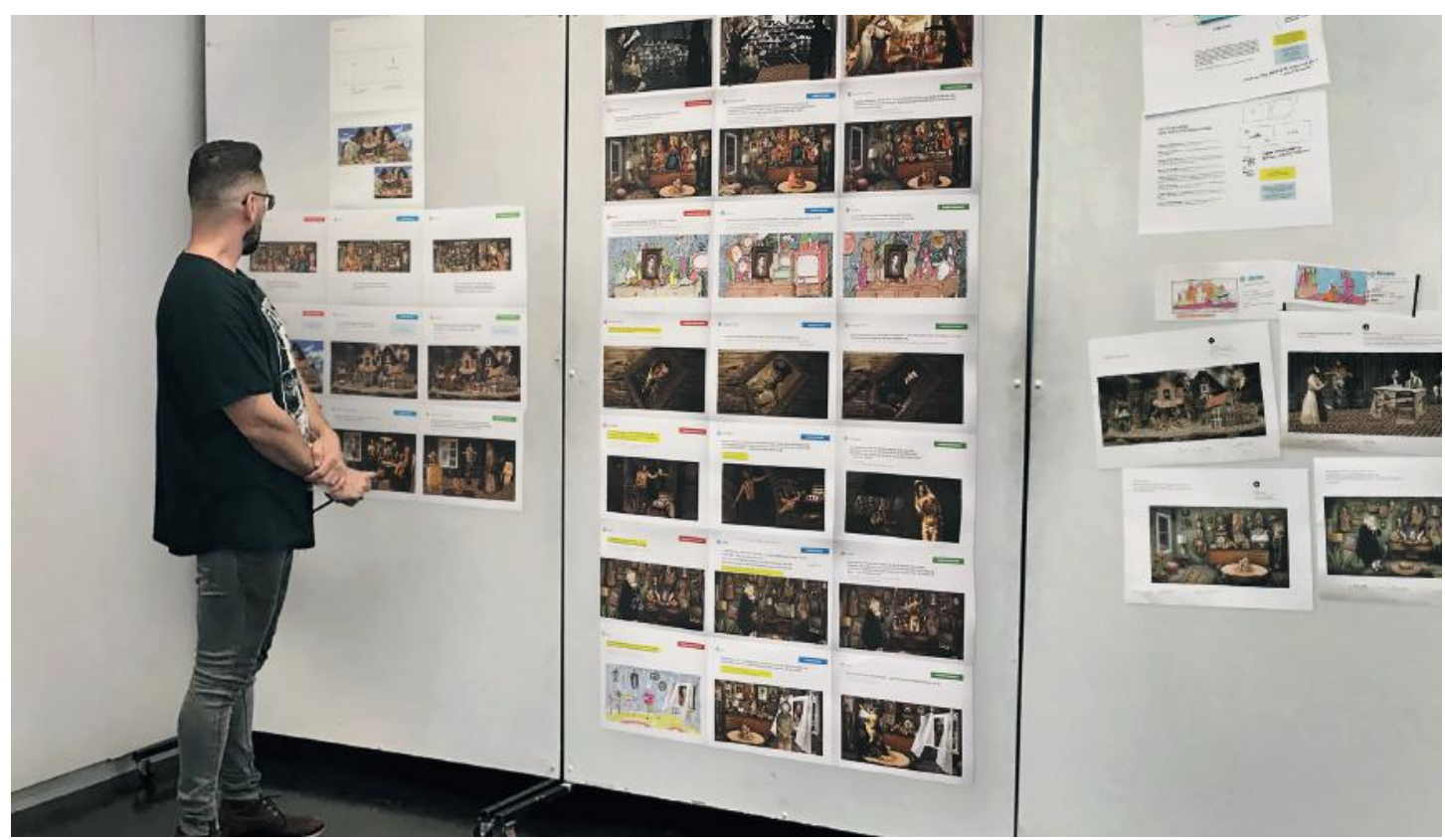

Fig 6. Uma visão geral da parede com um colega crítico considerando as 3 versões da história.

Fig 6. An overview wall with a critical colleague considering 3 versions of the story.

\section{Visualisation as overview}

Because of the complexity involved in designing a base narrative and three polyvocal interpretations, the researcher increasingly displayed the whole narrative as annotated illustrations on a wall (Fig 6). The images represented the major plot points in the story and, when assembled in their entirety, the process of overview enabled her to diagrammatically consider the story's arcs, transitions and discontinuities. By considering the book visually as a sequential narrative, she was able to easily realign scenes and write alteration notes to herself. While the overview wall initially provided a form of story-to-self dialogue, as the project developed the researcher brought in authors, illustrators, designers and narratologists to offer feedback on narrative clarity, emphasis and potential in the work. This method mitigated against the design becoming overly self-referential and as a consequence, losing its communicative power. 


\section{Feedback estratégico}

À medida que o projeto progrediu, a pesquisadora utilizou questionamentos cada vez mais estruturados para focalizar a crítica. Em sessões mais avançadas, animadores, técnicos de software e designers de som foram convidados a oferecer feedback sobre aspectos específicos do projeto. $0 \mathrm{fe}$ edback dessas críticas foi gravado em áudio ou fornecido como respostas por escrito às perguntas. As análises resultantes foram gravadas e sintetizadas em seu diário. As sessões de revisão avançadas foram programadas estrategicamente. Destas, duas foram significativas no desenvolvimento do projeto. A primeira foi uma exposição da polivocalização dos santos e a segunda uma instalação da estrutura geral da narrativa, pouco antes da realização do projeto.

Polyvocal Saints foi uma instalação de uma versão formativa da história dos três narradores. Cada santo sincrético foi projetado em uma parede separada e seu retrato foi ornamentado com recursos animados e uma trilha sonora em loop (Fig. 7). Nesse estágio da investigação, a pesquisadora ainda não estava preocupada com a narração, mas com a consideração de como cada santo poderia personificar qualidades e como elas poderiam operar em um espaço potencialmente polivocal. A instalação também foi usada para testar as propriedades técnicas do software, projeção, tempo e comportamento do público em um "espaço de leitura". Os resultados das observações e feedback sinalizaram desenvolvimentos futuros de polivocalidade e das personagens no projeto.

\section{Strategic feedback}

As the project progressed the researcher employed increasingly more structured questioning to focus critique. In more advanced sessions, animators, software technicians and sound designers were invited to offer feedback on specific aspects of the project. Feedback from these critiques was audio recorded or provided as written responses to questions. The resulting analyses were recorded and synthesised in her journal. The advanced review sessions were timed strategically. Of these, two were significant in the project's development. The first was an exhibition of the polyvocalising saints and the second was an installation of the overall narrative structure, just prior to the project's realisation.

Polyvocal Saints was an installation of a formative version of the story's three narrators. ${ }^{121}$ Each syncretic saint was projected on a separate wall and their portrait was embellished with animated features and a looped soundtrack ${ }^{122}$ (Fig 7). At this stage in the research, the researcher was not concerned with narration, but rather with a consideration of how each saint might personify character qualities and how they could operate in a potentially polyvocal space. The installation was also used to test the technical properties of software, projection, timing, and audience behaviour in a 'reading space'. The outcomes of observations and feedback informed future developments of polyvocality and character in the project. 


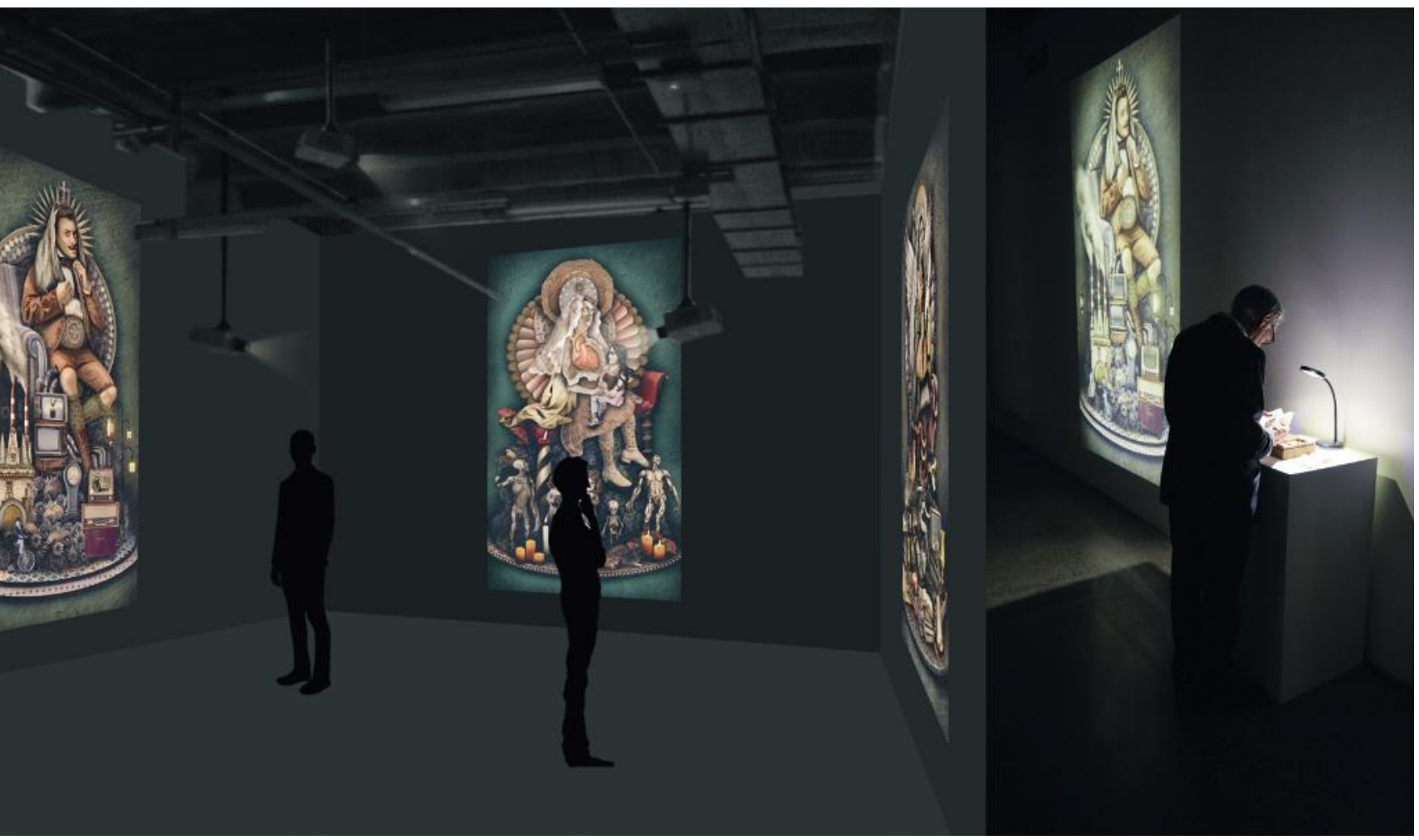

Fig 7. Instalação Polyvocal Saints.

A exibição pública aconteceu entre 26 e 28 de janeiro de 2017 na St Pauls Gallery 2, em Auckland, Nova Zelândia.
Fig 7. Polyvocal Saints installation.

The public viewing of the installation was open between 26-28 January 2017 at St Pauls Gallery 2, in Auckland, New Zealand.
A exposição da estrutura narrativa foi instalada 14 meses depois (Fig. 8), com a preocupação central em obter feedback sobre a coerência narrativa e a eficácia da polivocalidade ativada digitalmente. Os avaliadores não receberam qualquer esboço com orientação sobre a história. Em vez disso, foram equipados com um ipad contendo as narrações em áudio dos três santos. Com isso, escanearam as paredes contendo as dez placas sequenciais propostas da história. Em cada placa puderam selecionar qualquer santo para narrar uma versão do que foi encontrado. Os avaliadores tinham a opção de seguir a narração de um único santo ao
The narrative structure exhibition was installed 14 months later (Fig 8). It was concerned with eliciting feedback on narrative coherence and the effectiveness of digitally activated polyvocality. Reviewers were provided with no orienting outline of the story. Instead they were equipped with an ipad containing the three saint's audio narrations. With this they scanned walls containing the ten proposed sequential plates of the story. At each plate they were able to select any saint to narrate a version of what was encountered. The reviewers had the option of following a single saint's narration across the story or listening at each plate to all three saints' interpretations of the plot point. The critique session was conducted in one-on-one sessions across three 
longo da história ou ouvir em cada placa as interpretações de todos os três santos sobre a trama narrativa. A sessão crítica foi conduzida individualmente ao longo de três dias e envolveu nove avaliadores convidados e independentes. A natureza distinta do encontro significou que as perguntas poderiam ser direcionadas para a perícia específica do avaliador. Qualquer interpretação do trabalho permaneceu inalterada pela discussão ou ornamentar outras partes. days and it involved nine invited, independent reviewers. The discrete nature of the encounter meant that questions could be targeted at the specific expertise of the reviewer and any interpretation of the work remained unaffected by discussion or meaning embellishment from other parties.
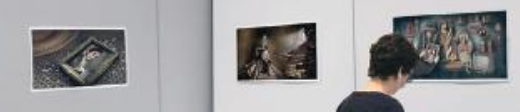

.
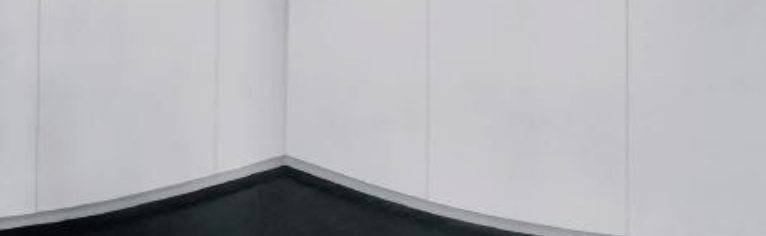

Fig 8. Exposição da estrutura narrativa.

Uma das revisoras, Dra. Lisa Williams, escutou a narração de um santo enquanto assistia às ilustrações e fazia anotações para posterior discussão.

\section{Conclusão}

A prática artística enquanto forma relativamente recente de pesquisa de doutorado teve sua desaprovação entre críticos. Foi acusada de desafiar o status de categorias de julgamento crítico na arte e de perturbar a cultura do conhecimento. ${ }^{57}$ Por outro lado, também foi creditada pela introdução de novas formas de "conhecimento incorporado" intrínsecos na academia. ${ }^{58}$ Além disso, a pesquisa artística em nível de doutorado mudou a maneira pela qual os

\section{Conclusion}

Artistic practice as a relatively recent form of doctoral research has had its critics. It has been accused of challenging the status of categories of critical judgement in $\operatorname{art}^{123}$ and disrupting the culture of knowledge. ${ }^{124}$ Conversely it has also been credited with introducing new forms of intrinsic "embodied knowledge" into the academy. ${ }^{125}$ In addition, artistic research at doctoral level has also changed the manner in which practitioners give a rigorous, critical and contextualising 'voice' to their thinking. A combination of practice and exegetical writing has 
Navigating artistic inquiry in a creative-production thesis: the narrative and illustrative potentials of realismo maravilhoso

realizadores dão uma "voz" rigorosa, crítica e contextualizada ao seu pensamento. Uma combinação de prática e escrita exegética resultou, consequentemente, em desafios ao papel tradicional do discreto teórico da arte. Isso ocorre porque a voz crítica do praticante tem, cada vez mais, começado a reivindicar e exercitar uma forma de análise acadêmica que inclui uma consideração e articulação de elementos de pesquisa que sustentam o trabalho, incluindo metodologia, métodos e pensamento contextual.

Embora ainda em desenvolvimento, a tese, Realidades mágicas - uma consideração criativa das potencialidades narrativas e ilustrativas do realismo maravilhoso, é um exemplo dessa agência (agency). Ao atuar no desenvolvimento iterativo da pesquisa, por meio de interconexões entre teoria e prática, a pesquisadora demonstra não apenas o desenvolvimento do pensamento, mas também a mecânica da revisão crítica que sustenta a realização de um artefato projetado.

A trajetória da pesquisa pode ser traçada através de um continuum que passou de processos flexíveis de investigação heurística internalizada para processos cada vez mais externalizados, nos quais o feedback crítico independente foi integrado à tomada de decisão artística. 0 processo, como tal, não é desconhecido. De fato, a busca sistemática do conhecimento pelo desenvolvimento de aplicativos incorporados em um artefato literário interativo é coerente com definições bem esta-

accordingly resulted in challenges to the traditional role of the discrete art theorist. This is because the critical voice of the practitioner has increasingly begun to claim and exercise a form of scholarly analysis that includes a consideration and articulation of research elements underpinning the work, including methodology, methods and contextual thinking.

Although still under development, the thesis, Magical realities - A creative consideration of the narrative and illustrative potentials of realismo maravilhoso, is an example of this agency. In actioning the iterative development of the research, through interconnections between theory and practice, the researcher demonstrates not only the development of thinking but also the mechanics of critical review underpinning the realisation of a designed artefact.

The research trajectory can be traced across a continuum that has moved from flexible processes of internalised, heuristic inquiry, towards increasingly externalised processes, where independent critical feedback has been integrated into artistic decision making. The process as such, is not an unfamiliar one. In fact, the study's systematic pursuit of knowledge to develop applications embedded in an interactive literary artefact is congruent with well-established definitions of research. Perhaps a 2008 UNESCO definition serves as an example. 
belecidas da pesquisa. Talvez uma definição de 2008 da UNESCO sirva de exemplo.

Ela define pesquisa como "qualquer atividade sistemática criativa empreendida para aumentar o acervo de conhecimento, incluindo o conhecimento do homem, da cultura e da sociedade, e o uso desse conhecimento para criar novas aplicações". ${ }^{59}$

Tal definição e os princípios da investigação artística em nível de doutorado estão em consonância.

It defines research as, "any creative systematic activity undertaken in order to increase the stock of knowledge, including knowledge of man, culture and society, and the use of this knowledge to devise new applications."126

Such a definition and the tenets of doctoral level artistic inquiry are entirely congruent.

1 Julian Klein. "What Is Artistic Research?" Gegenworte - Berlin-Brandenburgische Akademie der Wissenschaften 23 (2010).

2 Stephen Scrivener. "Characterising Creative-Production Doctoral Projects in Art and Design," International Journal of Design Sciences and Technology 10, no. 2 (2002).

3 OECD. Frascati Manual 2015: Guidelines for Collecting and Reporting Data on Research and Experimental Development (Paris: OECD Publishing, 2015): 28.

4 Arts and Humanities Research Board. "Guide to the Research Grant Scheme," http://www.ahrb.ac.uk/research/grant/guide.htm

5 Graeme Sullivan. Art Practice as Research: Inquiry in Visual Arts (Sage, 2010):

6 Brad Buckley and John Conomos. Rethinking the Contemporary Art School: The Artist, the PhD, and the Academy (The Press of the Nova Scotia College of Art and Design, 2009): 88.

7 Catherine Heard. Review of Rethinking the Contemporary Art School: The Artist, the PhD, and the Academy. Brad Buckley and John Conomos, RACAR: Revue d'art Canadienne / Canadian Art Review 35, no. 2 (2010): 81.

8 Timothy Emlyn Jones. "The PhD in Art \& Design" (Paper presented at the ELIA Comhar Conference, Dublin, 2002).

9 Dennis Strand. Research in the Creative Arts, vol. 98 (Department of Employment, Education, Training and Youth Affairs Canberra, 1998).

10 Christopher Frayling. "Research in Art and Design," Royal College of Art Research Papers 1, no. 1 (1993): 2.

11 Linda Candy. "Practice Based Research: A Guide," Creativity \& Cognition Studios 1 (2006): 2.

12 Heard, 81.

13 Fred R. Schwartz. "Graduate Education in the Fine Arts," Art Education 25, no. 7 (1972).

14 Jillian G. Hamilton. "The Voices of the Exegesis." In Practice, Knowledge, Vision: Doctoral Education in Design, ed. Friedman Ken and Lorain Justice (Hong Kong Polytechnic University, School of Design: Queensland University of Technology, 2011); ibid.

15 Klein. "What Is Artistic Research?," 4.

16 lbid.

17 Ibid., 6.

18 Henk Borgdorff. Artistic Research and Academia: An Uneasy Relationship (Swedish Research Council, 2008), 91.

DATJournal v.3 ก.2 2018 
Navigating artistic inquiry in a creative-production thesis: the narrative and illustrative potentials of realismo maravilhoso

19 Martin Heidegger. "The Question of Technology and Other Essays," Trans. W. Lovett. New York: Harper and Row (1977).

20 Barbara Bolt. "Heidegger, Handlability and Praxical Knowledge" (Paper presented at the Australian Council of University Art and Design Schools Conference, Canberra, 2004), 1.

21 Nigel Cross. "Designerly Ways of Knowing: Design Discipline Versus Design Science," Design Issues 17, no. 3 (2001); Maarit Mäkelä. "Knowing through Making: The Role of the Artefact in Practice-led Research," Knowledge, Technology \& policy 20 (2007); Stephen Scrivener. "Characterising Creative-production Doctoral Projects in Art and Design."; "The Art Object Does Not Embody a Form of Knowledge," (England: University of Hertfordshire, 2002); Carole Gray. "Inquiry through Practice: Developing Appropriate Research Strategies," No Guru, No Method? (1996).

22 Scrivener. "Characterising Creative-Production Doctoral Projects in Art and Design," 26.

23 Ibid., 34.

24 Ibid., 31.

25 Brad Haseman. "A Manifesto for Performative Research," Media International Australia incorporating Culture and Policy 118, no. 1 (2006): 100

26 Michael Biggs. "The Role of Context in Art and Design Research," (2006).

27 Scrivener. "Characterising Creative-Production Doctoral Projects in Art and Design."

28 Mäkelä. "Knowing through Making: The Role of the Artefact in Practice-Led Research," 160

29 Barbara Bolt. "Materializing Pedagogies?", https://www.herts. ac.uk/_data/assets/pdf_file/0015/12381/WPIAAD_vol4_bolt.pdf. 30 Hamilton. "The Voices of the Exegesis."; Welby Ings. "The Authored Voice: Emerging Approaches to Exegesis Design in Creative Practice PhDs," Educational Philosophy and Theory 47, no. 12 (2015).

31 Elaine Thomas. "Research Training in the Creative and Performing Arts and Design," Lichfield: UK Council for Graduate Education (2001).

32 Arjun Appadurai. Modernity at Large: Cultural Dimensions of Globalization (Minneapolis: University of Minnesota Press, 1996); Stephen Slemon. "Magic Realism as Post-Colonial Discourse," Canadian Literature 116 (1988); "Magic Realism as Postcolonial Discourse." In Magical Realism: Theory, History, Community, eds. Lois Parkinson Zamora and Wendy B. Faris (United States of America: Duke University Press, 1995); William Splinder. "Magic Realism: A Typology," Forum for Modern Language 34, no. 1 (1993); Lois Parkin- son Zamora and Wendy B. Faris. Magical Realism: Theory, History, Community (United States of America: Duke University Press, 1995); Wendy B. Faris. Ordinary Enchantments: Magical Realism and the Remystification of Narrative (Nashville: Vanderbilt University Press. 2004).

33 Sincretismo é originalmente usado para descrever a fusão ou a "prática dual" de dois sistemas religiosos. Charles Stewart "Creolization, Hybridity, Syncretism, Mixture", Portuguese Studies, n. 1 (2011). Em um contexto brasileiro, o sincretismo é aplicado à fusão de deuses indígenas e africanos com santos católicos em cultos Afro-Brasileiros. Basil Calvin Hedrick. The Afro-Brazilian Fetish Cults: Religious Syncretism (Grambling College Liberal Arts Bulletin, 1967). Arthur Ramos argumenta que os negros brasileiros eram "católicos, mas por trás do culto dos santos e das cerimônias católicas eles continuam adorando seus antigos deuses africanos". Arthur Ramos. "Acculturation among the Brazilian Negroes," The Journal of Negro History 26, no. 2 (1941): 247-48.

0 sincretismo é originalmente usado para descrever a fusão ou a "prática dual" de dois sistemas religiosos. Charles Stewart. "Creolization, Hybridity, Syncretism, Mixture," Portuguese Studies, no. 1 (2011). Em um contexto brasileiro, o sincretismo é aplicado à fusão de deuses indígenas e africanos com santos católicos em cultos Afro-Brasileiros. Basil Calvin Hedrick. The Afro-Brazilian Fetish Cults: Religious Syncretism (Grambling College Liberal Arts Bulletin, 1967). Arthur Ramos argumenta que os negros brasileiros eram "católicos, mas por trás do culto dos santos e das cerimônias católicas eles continuam adorando seus antigos deuses africanos". Arthur Ramos. "Acculturation among the Brazilian Negroes," The Journal of Negro History 26, no. 2 (1941): 247-48.

34 Roger Bastide. Problems of Religious Syncretism, trans. Helen Sebba, The African Religions of Brazil. Towards a Sociology of the Interpretation of Civilizations (Baltimore and London: Johns Hopkins University Press, 1960).

350 termo polivocalidade refere-se a múltiplos narradores ou perspectivas variadas de diferentes personagens ou narradores dentro de um texto. É frequentemente associado na teoria da literatura e estudos sociais aos escritos do filósofo russo Mikhail Bakhtin e os conceitos de polifonia e dialogismo. Mikhail Bakhtin. Problems of Dostoevsky's Poetics, vol. 8 (Minneapolis, MN: University of Minnesota Press, 1984); "Dostoevsky's Polyphonic Novel and Its Treatment in Critical Literature," in Problems of Dostoevsky's Poetics, ed. Caryl Emerson (Minneapolis: University of Minnesota, 1984). Problems of Dostoevsky's Poetics, 8; Rabelais and His World (Bloomington: Indiana University Press, 1984). 
36 Problems of Dostoevsky's Poetics, 8; Rebelais and His World, trans. Hélène Iswolsky (Moscow: Indiana University Press, 1965). 37 Donald Schön. The Reflexive Practitioner: How Professionals Think in Action. (New York, NY: Basic, 1983).

38 Bruce G. Douglass and Clark Moustakas. "Heuristic Enquiry the Internal Search," Journal of Humanistic Psychology 25, no. 3 (1985); Clark Moustakas. Heuristic Research: Design, Methodology, and Applications (Thousand Oaks, CA: SAGE, 1990); Gerhard Kleining and Harald Witt. "The Qualitative Heuristic Approach: A Methodology for Discovery in Psychology and the Social Sciences. Rediscovering the Method of Introspection as an Example," 113 (2000); Sandy Sela-Smith. "Heuristic Research: A Review and Critique of Moustakas's Method," Journal of Humanistic Psychology 42, no. 3 (2002); Welby Ings. "Managing Heuristics as a Method of Inquiry in Autobiographical Graphic Design Theses," (2011).

39 Kleining and Witt. "The Qualitative Heuristic Approach: A Methodology for Discovery in Psychology and the Social Sciences. Rediscovering the Method of Introspection as an Example."

40 Michael Polanyi. The Tacit Dimension (Garden City, NY: Doubleday, 1966), 32.

41 Moustakas. Heuristic Research : Design, Methodology, and Applications, 32 .

42 Douglass and Moustakas. "Heuristic Enquiry the Internal Search," 47. $43 \mathrm{lbid}$.

44 Ibid., 47.

45 Moustakas. Heuristic Research: Design, Methodology, and Applications, 43.

46 Polanyi. The Tacit Dimension; Ings. "The Authored Voice: Emerging Approaches to Exegesis Design in Creative Practice PhDs," Educational Philosophy and Theory 47, no. 12 (2014).

47 Douglass and Moustakas. "Heuristic Enquiry the Internal Search," 47. 48 Carole Gray and Julian Malins. Visualizing Research: A Guide to the Research Process in Art and Design (England: Ashgate, 2004), 59. 49 Paul A. Rodgers, Graham Green, and Alistair McGown. "Using Concept Sketches to Track Design Progress," Design Studies 21 (2000): 452

50 Kleining and Witt. "The Qualitative Heuristic Approach: A Methodology for Discovery in Psychology and the Social Sciences. Rediscovering the Method of Introspection as an Example," 3

51 Terry E. Rosenberg. "New Beginnings and Monstrous Births: Notes Towards an Appreciation of Ideational Drawing," (2008): 248. 52 Schön. The Reflexive Practitioner: How Professionals Think in Action., 79.

53 Ibid.

54 Ibid., 132.

55 Ings. "Managing Heuristics as a Method of Inquiry in Autobiographical Graphic Design Theses."
56 Ings. "Managing Heuristics as a Method of Inquiry in Autobiographical Graphic Design Theses," 10.

57 Kathrin Busch. "Generating Knowledge in the Arts - a Philosophical Daydream," Texte zur Kunst 82 (2011): 72-73.

58 Klein. "What is Artistic Research?."

59 OECD. "Glossary of Statistical Terms. " https://stats.oecd.org/ glossary/detail.asp?!D=2312.

60 Julian Klein, "What Is Artistic Research?," Gegenworte - Berlin-Brandenburgische Akademie der Wissenschaften 23 (2010).

61 Stephen Scrivener, "Characterising Creative-Production Doctoral Projects in Art and Design," International Journal of Design Sciences and Technology 10, no. 2 (2002).

62 OECD, Frascati Manual 2015: Guidelines for Collecting and Reporting Data on Research and Experimental Development (Paris: OECD Publishing, 2015), 28.

63 Arts and Humanities Research Board, "Guide to the Research Grant Scheme," http://www.ahrb.ac.uk/research/grant/guide.htm 64 Graeme Sullivan, Art Practice as Research: Inquiry in Visual Arts (Sage, 2010), 6.

65 Brad Buckley and John Conomos, Rethinking the Contemporary Art School: The Artist, the Phd, and the Academy (The Press of the Nova Scotia College of Art and Design, 2009), 88.

66 Catherine Heard, review of Rethinking the Contemporary Art School: The Artist, the PhD, and the Academy, Brad Buckley, John Conomos, RACAR: revue d'art canadienne / Canadian Art Review 35 , no. 2 (2010): 81

67 Timothy Emlyn Jones, "The Phd in Art \& Design" (paper presented at the ELIA Comhar Conference, Dublin, 2002).

68 Dennis Strand, Research in the Creative Arts, vol. 98 (Department of Employment, Education, Training and Youth Affairs Canberra, 1998).

69 Christopher Frayling, "Research in Art and Design," Royal College of Art Research Papers 1, no. 1 (1993): 2.

70 Linda Candy, "Practice Based Research: A Guide," Creativity \& Cognition Studios 1 (2006): 2.

71 Heard, 81.

72 Fred R Schwartz, "Graduate Education in the Fine Arts," Art Education 25, no. 7 (1972).

73 Jillian G Hamilton, "The Voices of the Exegesis," in Practice Knowledge, Vision: Doctoral Education in Design, ed. Ken Friedman and Lorain Justice (Hong Kong Polytechnic University, School of Design: Queensland University of Technology, 2011); ibid.

74 Klein, "What Is Artistic Research?" 4.

75 Ibid.

76 Ibid., 6.

77 Henk Borgdorff, Artistic Research and Academia: An Uneasy Relationship (Swedish research council, 2008), 91. 
Navigating artistic inquiry in a creative-production thesis: the narrative and illustrative potentials of realismo maravilhoso

78 Martin Heidegger, "The Question of Technology and Other Essays," Trans. W. Lovett. New York: Harper and Row (1977).

79 Barbara Bolt, "Heidegger, Handlability and Praxical Knowledge" (paper presented at the Australian Council of University Art and Design Schools Conference, Canberra, 2004), 1.

80 Nigel Cross, "Designerly Ways of Knowing: Design Discipline Versus Design Science," Design Issues 17, no. 3 (2001); Maarit Mäkelä, "Knowing through Making: The Role of the Artefact in Practice-Led Research," Know Techn Pol 20 (2007); Scrivener, "Characterising Creative-Production Doctoral Projects in Art and Design."; "The Art Object Does Not Embody a Form of Knowledge," (England: University of Hertfordshire, 2002); Carole Gray, "Inquiry through Practice: Developing Appropriate Research Strategies," No Guru, No Method? (1996).

81 Scrivener, "Characterising Creative-Production Doctoral Projects in Art and Design," 26.

82 Ibid., 34.

83 Ibid., 31

84 Brad Haseman, "A Manifesto for Performative Research," Media International Australia incorporating Culture and Policy 118, no. 1 (2006): 100

85 Michael Biggs, "The Role of Context in Art and Design Research," Working Papers in Art and Design 4 (2006).

86 Scrivener, "Characterising Creative-Production Doctoral Projects in Art and Design."

87 Mäkelä, "Knowing through Making: The Role of the Artefact in Practice-Led Research," 160.

88 Barbara Bolt, "Materializing Pedagogies?," 2018 (2006), https:// www.herts.ac.uk/_data/assets/pdf_file/0015/12381/WPIAAD_vol4_ bolt.pdf.

89 Hamilton, "The Voices of the Exegesis."; Welby Ings. "The Authored Voice: Emerging Approaches to Exegesis Design in Creative Practice PhDs," Educational Philosophy and Theory 47, no. 12 (2015).

90 Elaine Thomas, "Research Training in the Creative and Performing Arts and Design," Lichfield: UK Council for Graduate Education (2001).

91 The English terms magic realism, magic(al) realism, magical realism and marvellous realism are related and have been used to discuss types of magic and different applications in art and literature. In Latin American contexts, Alejo Carpentier used the term lo real maravilloso (marvellous real) to posit an original Latin American voice for magical realism in literature and he suggested that specific historical and geographic conventions distinguish it from other forms of magical realism. Writers who have been influentail in these debates include: Maggie Ann Bowers, Magic(Al) Realism (Oxon: Routledge, 2004); Angel Flores, "Magical Realism in Spanish
American Literature," in Magical Realism: Theory, History, Community, ed. Lois Parkinson Zamora and Wendy B. Faris (United States of America: Duke University Press, 1955); Roh, Nach Expressionismus: Magischer Realismus: Probleme Der Neuesten Europäischen Malerei (after Expressionism: Magical Realism: Problems of the Newest European Painting); Ana Margarida Fonseca, "Desafios Da Mestiçagem: o Realismo Mágico Em Questão," Veredas: Revista da Associação Internacional de Lusitanistas, no. 7. Alejo Carpentier, "El Reino De Este Mundo," http//:amauta.lahaine.org. Theodore Robert Young, "Um Realismo Mágico no Brasil?: Um Levantamento," Mester 24, no. 1 (1995); Irlemar Chiampi, O Realismo Maravilhoso: Forma E Ideologia No Romance Hispano-Americano. (São Paulo: Perspectiva, 1980).

92 There is a substantial body of literature impacting on this idea. Useful to this study have been the following texts: Arjun Appadurai, Modernity at Large: Cultural Dimensions of Globalization (Minneapolis: University of Minnesota Press, 1996); Stephen Slemon, "Magic Realism as Post-Colonial Discourse," Canadian Literature 116 (1988); "Magic Realism as Postcolonial Discourse," in Magical Realism: Theory, History, Community, ed. Lois Parkinson Zamora and Wendy B. Faris (United States of America: Duke University Press, 1995); William Splinder, "Magic Realism: A Typology," Forum for Modern Language 34, no. 1 (1993); Lois Parkinson Zamora and Wendy B. Faris, Magical Realism: Theory, History, Community (United States of America: Duke University Press, 1995); Wendy B. Faris, Ordinary Enchantments: Magical Realism and the Remystification of Narrative (Nashville: Vanderbilt University Press., 2004).

93 Syncretism is originally used to describe the merging or the 'dual practice' of two religious systems. Charles Stewart, "Creolization, Hybridity, Syncretism, Mixture," Portuguese Studies, no. 1 (2011). In a Brazilian context, syncretism is applied to the merging of indigenous and African gods with Catholic saints in Brazilian Afro-Brazilian cults. Useful texts relating to this idea include: Sérgio F. Ferretti, "Notas sobre o sincretismo religioso no Brasil - Modelos, limitações e possibilidades," Tempo 6, no. 11 (2001). Basil Calvin Hedrick, The Afro-Brazilian Fetish Cults: Religious Syncretism (Grambling College Liberal Arts Bulletin, 1967). Arthur Ramos argues that the Brazilian negroes were "Catholics, but behind the cult of the saints and the Catholic ceremonies they continue worshiping their old African gods." Arthur Ramos, "Acculturation among the Brazilian Negroes," The Journal of Negro History 26, no. 2 (1941): 247-48.

94 Roger Bastide, Problems of Religious Syncretism, trans. Helen Sebba, The African Religions of Brazil. Towards a Sociology of the Interpretation of Civilizations (Baltimore and London: Johns Hopkins University Press, 1960)

95 The term polyvocality refers to multiple narrators or varied perspectives from different characters or narrators within a text. It's often associated in literature theory and social studies to the 
writings of Russian philosopher Mikhail Bakhtin and the concepts of polyphony and dialogism. Mikhail Bakhtin, Problems of Dostoevsky's Poetics, vol. 8 (Minneapolis, MN: University of Minnesota Press, 1984); "Dostoevsky's Polyphonic Novel and Its Treatment in Critical Literature," in Problems of Dostoevsky's Poetics, ed. Caryl Emerson (Minneapolis: University of Minnesota, 1984). Problems of Dostoevsky's Poetics, 8; Rabelais and His World (Bloomington: Indiana University Press, 1984).

96 Problems of Dostoevsky's Poetics, 8; Rebelais and His World, trans. Hélène Iswolsky (Moscow: Indiana University Press, 1965). 97 Donald Schön, The Reflexive Practitioner: How Professionals Think in Action. (New York, NY: Basic, 1983).

98 Bruce G. Douglass and Clark Moustakas, "Heuristic Enquiry the Internal Search," Journal of Humanistic Psychology 25, no. 3 (1985); Clark Moustakas, Heuristic Research: Design, Methodology, and Applications (Thousand Oaks, CA: SAGE, 1990); Gerhard Kleining and Harald Witt, "The Qualitative Heuristic Approach: A Methodology for Discovery in Psychology and the Social Sciences. Rediscovering the Method of Introspection as an Example," 113 (2000); Sandy Sela-Smith, "Heuristic Research: A Review and Critique of Moustakas's Method," Journal of Humanistic Psychology 42, no. 3 (2002); Welby Ings, "Managing Heuristics as a Method of Inquiry in Autobiographical Graphic Design Theses," (2011).

99 Kleining and Witt, "The Qualitative Heuristic Approach: A Methodology for Discovery in Psychology and the Social Sciences. Rediscovering the Method of Introspection as an Example."

100 Michael Polanyi, The Tacit Dimension (Garden City, NY: Doubleday, 1966), 32.

101 Moustakas, Heuristic Research: Design, Methodology, and Applications, 32.

102 Douglass and Moustakas, "Heuristic Enquiry the Internal Search," 47.

103 lbid.

104 Ibid., 47

105 Moustakas, Heuristic Research: Design, Methodology, and Applications, 43.

106 Polanyi, The Tacit Dimension; Welby Ings, "The Authored Voice: Emerging Approaches to Exegesis Design in Creative Practice Phds", Educational Philosophy and Theory 47, no. 12 (2014).

107 Douglass and Moustakas, "Heuristic Enquiry the Internal Search," 47.

108 Carole Gray and Julian Malins, Visualizing Research: A Guide to the Research Process in Art and Design (England: Ashgate, 2004), 59. 109 Paul A. Rodgers, Graham Green, and Alistair McGown, "Using
Concept Sketches to Track Design Progress," Design Studies 21 (2000): 452.

110 Kleining and Witt, "The Qualitative Heuristic Approach: A Methodology for Discovery in Psychology and the Social Sciences. Rediscovering the Method of Introspection as an Example," 3.

111 Terry E Rosenberg, "New Beginnings and Monstrous Births: Notes Towards an Appreciation of Ideational Drawing," (2008): 248. 112 Schön, The Reflexive Practitioner: How Professionals Think in Action., 79

113 Ibid., 146

114 Ibid., 145.

115 Ibid.

116 Ibid., 132

117 Gray, "Inquiry through Practice: Developing Appropriate Research Strategies."; Ings, "Managing Heuristics as a Method of Inquiry in Autobiographical Graphic Design Theses," 77.

118 Ings. "Managing Heuristics as a Method of Inquiry in Autobiographical Graphic Design Theses."

119 Sela-Smith discusses this idea in terms of the disjointed nature between verbalised language and thought-based self-experience. She describes the tacit knowledge as "preverbal and disconnected from the verbal-thinking self." Sela-Smith, "Heuristic Research: A Review and Critique of Moustakas's Method," 62.

120 Ings, "Managing Heuristics as a Method of Inquiry in Autobiographical Graphic Design Theses," 10.

121 The three Saints drew on the Christian concept of a trinity featuring three consubstantial beings or hypostases. As in the trinity, the three Saints were distinct, but they differed because they were not of one "substance, essence or nature" (homoousios) Fourth Lateran Council, "Catechism of the Catholic Church," http://www.vatican.va/archive/ ccc_css/archive/catechism/p1s2c1p2.htm. In other words, in the story they think and operate discretely, having different perspectives, beliefs and emphases.

122 This audio mix formed a proposed soundscape that would accompany them when they spoke in the final work.

123 Sebastian Mühl, "Artistic Research as a Challenge for Art Criticism," Notebook for art, theory and related zones 20 (2016), http:// vvp.avu.cz/wp-content/uploads/2016/12/muhl.pdf.

124 Kathrin Busch, "Generating Knowledge in the Arts - a Philosophical Daydream," Texte zur Kunst 82 (2011): 72-73.

125 Klein, "What Is Artistic Research?."

126 OECD, "Glossary of Statistical Terms " https://stats.oecd.org/ glossary/detail.asp?!D=2312. 
Navigating artistic inquiry in a creative-production thesis: the narrative and illustrative potentials of realismo maravilhoso

\section{Referências bibliográficas}

Appadurai, Arjun. Modernity at Large: Cultural Dimensions of Globalization. Minneapolis: University of Minnesota Press, 1996.

Bakhtin, Mikhail. "Dostoevsky's Polyphonic Novel and Its Treatment in Critical Literature." Translated by Caryl Emerson. In Problems of Dostoevsky's Poetics, edited by Caryl Emerson, 5-45. Minneapolis: University of Minnesota, 1984.

Bakhtin, Mikhail. Problems of Dostoevsky's Poetics. Vol. 8, Minneapolis, MN: University of Minnesota Press, 1984.

Bakhtin, Mikhail. Rabelais and His World. Bloomington: Indiana University Press, 1984.

Bakhtin, Mikhail. Rebelais and His World. Translated by Hélène Iswolsky. Moscow: Indiana University Press, 1965.

Bastide, Roger. Problems of Religious Syncretism. Translated by Helen Sebba. The African Religions of Brazil. Towards a Sociology of the Interpretation of Civilizations. Baltimore and London: Johns Hopkins University Press, 1960.

Biggs, Michael. "The Role of Context in Art and Design Research." Working Papers in Art and Design 4 (2006).

Board, Arts and Humanities Research. "Guide to the Research Grant Scheme." http://www.ahrb.ac.uk/ research/grant/guide.htm

Bolt, Barbara. "Heidegger, Handlability and Praxical Knowledge." Paper presented at the Australian Council of University Art and Design Schools Conference, Canberra, 2004.

Bolt, Barbara. "Materializing Pedagogies?". https://www.herts.ac.uk/_data/assets/pdf_ file/0015/12381/WPIAAD_vol4_bolt.pdf.

Borgdorff, Henk. Artistic Research and Academia: An Uneasy Relationship. Swedish research council, 2008. Buckley, Brad, and John Conomos. Rethinking the Contemporary Art School: The Artist, the PhD, and the Academy. The Press of the Nova Scotia College of Art and Design, 2009.

Busch, Kathrin. "Generating Knowledge in the Arts - a Philosophical Daydream." Texte zur Kunst 82 (2011): 70-79.

Candy, Linda. "Practice Based Research: A Guide." Creativity \& Cognition Studios 1 (2006).

\section{References}

Appadurai, Arjun. Modernity at Large: Cultural Dimensions of Globalization. Minneapolis: University of Minnesota Press, 1996.

Bakhtin, Mikhail. "Dostoevsky's Polyphonic Novel and Its Treatment in Critical Literature." Translated by Caryl Emerson. In Problems of Dostoevsky's Poetics, edited by Caryl Emerson, 5-45. Minneapolis: University of Minnesota, 1984.

Bakhtin, Mikhail. Problems of Dostoevsky's Poetics. Vol. 8, Minneapolis, MN: University of Minnesota Press, 1984.

Bakhtin, Mikhail. Rabelais and His World. Bloomington: Indiana University Press, 1984.

Bakhtin, Mikhail. Rebelais and His World. Translated by Hélène Iswolsky. Moscow: Indiana University Press, 1965.

Bastide, Roger. Problems of Religious Syncretism. Translated by Helen Sebba. The African Religions of Brazil. Towards a Sociology of the Interpretation of Civilizations. Baltimore and London: Johns Hopkins University Press, 1960.

Biggs, Michael. "The Role of Context in Art and Design Research." Working Papers in Art and Design 4 (2006).

Board, Arts and Humanities Research. "Guide to the Research Grant Scheme." http://www.ahrb.ac.uk/ research/grant/guide.htm

Bolt, Barbara. "Heidegger, Handlability and Praxical Knowledge." Paper presented at the Australian Council of University Art and Design Schools Conference, Canberra, 2004.

Bolt, Barbara. “Materializing Pedagogies?". https://www.herts.ac.uk/__data/assets/pdf_ file/0015/12381/WPIAAD_vol4_bolt.pdf.

Borgdorff, Henk. Artistic Research and Academia: An Uneasy Relationship. Swedish research council, 2008. Buckley, Brad, and John Conomos. Rethinking the Contemporary Art School: The Artist, the PhD, and the Academy. The Press of the Nova Scotia College of Art and Design, 2009.

Busch, Kathrin. "Generating Knowledge in the Arts - a Philosophical Daydream." Texte zur Kunst 82 (2011): 70-79.

Candy, Linda. "Practice Based Research: A Guide." Creativity \& Cognition Studios 1 (2006). 
Council, Fourth Lateran. "Catechism of the Catholic church." http://www.vatican.va/archive/ccc_css/ archive/catechism/p1s2c1p2.htm.

Cross, Nigel. "Designerly Ways of Knowing: Design Discipline Versus Design Science." Design Issues 17, no. 3 (2001): 49-55.

Douglass, Bruce G., and Clark Moustakas. "Heuristic Enquiry the Internal Search." Journal of Humanistic Psychology 25, no. 3 (1985): 39-55.

Faris, Wendy B. Ordinary Enchantments: Magical Realism and the Remystification of Narrative. Nashville: Vanderbilt University Press., 2004.

Frayling, Christopher. "Research in Art and Design." Royal College of Art Research Papers 1, no. 1 (1993): 1-5. Gray, Carole. "Inquiry through Practice: Developing Appropriate Research Strategies." No Guru, No Method? (1996): 1-28.

Gray, Carole, and Julian Malins. Visualizing Research: A Guide to the Research Process in Art and Design. England: Ashgate, 2004.

Hamilton, Jillian G. "The Voices of the Exegesis." In Practice, Knowledge, Vision: Doctoral Education in Design, edited by Ken Friedman and Lorain Justice. Hong Kong Polytechnic University, School of Design: Queensland University of Technology, 2011.

Haseman, Brad. "A Manifesto for Performative Research." Media International Australia incorporating Culture and Policy 118, no. 1 (2006): 98-106.

Heard, Catherine. Review of Rethinking the Contemporary Art School: The Artist, the PhD, and the Academy. Brad Buckley and John Conomos. RACAR: Revue d'art Canadienne / Canadian Art Review 35, no. 2 (2010): 81-83.

Hedrick, Basil Calvin. The Afro-Brazilian Fetish Cults: Religious Syncretism. Grambling College Liberal Arts Bulletin, 1967.

Heidegger, Martin. "The Question of Technology and Other Essays." Trans. W. Lovett. New York: Harper and Row, (1977).

Ings, Welby. "The Authored Voice: Emerging Approaches to Exegesis Design in Creative Practice PhDs." Educational Philosophy and Theory 47, no. 12 (2014): 1277-90.

Ings, Welby. "Managing Heuristics as a Method of Inquiry in Autobiographical Graphic Design Theses." (2011). Jones, Timothy Emlyn. “The PhD in Art \& Design." Paper presented at the ELIA Comhar Conference, Dublin, 2002.
Chiampi, Irlemar. O Realismo Maravilhoso: Forma E Ideologia No Romance Hispano-Americano. São Paulo: Perspectiva, 1980.

Council, Fourth Lateran. "Catechism of the Catholic church." http://www.vatican.va/archive/ccc_css/ archive/catechism/p1s2c1p2.htm.

Cross, Nigel. "Designerly Ways of Knowing: Design Discipline Versus Design Science.” Design Issues 17, no. 3 (2001): 49-55.

Douglass, Bruce G., and Clark Moustakas. "Heuristic Enquiry the Internal Search.” Journal of Humanistic Psychology 25, no. 3 (1985): 39-55.

Faris, Wendy B. Ordinary Enchantments: Magical Realism and the Remystification of Narrative. Nashville: Vanderbilt University Press., 2004.

Frayling, Christopher. "Research in Art and Design." Royal College of Art Research Papers 1, no. 1 (1993): 1-5.

Gray, Carole. "Inquiry through Practice: Developing Appropriate Research Strategies." No Guru, No Method? (1996): 1-28.

Gray, Carole, and Julian Malins. Visualizing Research: A Guide to the Research Process in Art and Design. England: Ashgate, 2004.

Hamilton, Jillian G. "The Voices of the Exegesis." In Practice, Knowledge, Vision: Doctoral Education in Design, edited by Ken Friedman and Lorain Justice. Hong Kong Polytechnic University, School of Design: Queensland University of Technology, 2011.

Haseman, Brad. "A Manifesto for Performative Research." Media International Australia incorporating Culture and Policy 118, no. 1 (2006): 98-106.

Heard, Catherine. Review of Rethinking the Contemporary Art School: The Artist, the PhD, and the Academy. Brad Buckley and John Conomos. RACAR: Revue d'art Canadienne / Canadian Art Review 35, no. 2 (2010): 81-83.

Hedrick, Basil Calvin. The Afro-Brazilian Fetish Cults: Religious Syncretism. Grambling College Liberal Arts Bulletin, 1967.

Heidegger, Martin. “The Question of Technology and Other Essays.” Trans. W. Lovett. New York: Harper and Row, (1977).

Ings, Welby. "The Authored Voice: Emerging Approaches to Exegesis Design in Creative Practice PhDs." Educational Philosophy and Theory 47, no. 12 (2014): 1277-90. 
Klein, Julian. “What Is Artistic Research?”. Gegenworte - Berlin-Brandenburgische Akademie der Wissenschaften 23 (2010): 1-6.

Kleining, Gerhard, and Harald Witt. "The Qualitative Heuristic Approach: A Methodology for Discovery in Psychology and the Social Sciences. Rediscovering the Method of Introspection as an Example." 113 (2000).

Mäkelä, Maarit. "Knowing through Making: The Role of the Artefact in Practice-Led Research." Know Techn Pol 20 (2007): 157-63.

Moustakas, Clark. Heuristic Research: Design, Methodology, and Applications. Thousand Oaks, CA: SAGE, 1990. doi:10.4135/9781412995641.

Mühl, Sebastian. "Artistic Research as a Challenge for Art Criticism." Notebook for art, theory and related zones 20 (2016): 1-13. http://vvp.avu.cz/wp-content/ uploads/2016/12/muhl.pdf.

OECD. Frascati Manual 2015: Guidelines for Collecting and Reporting Data on Research and Experimental Development. Paris: OECD Publishing, 2015.

OECD. "Glossary of Statistical Terms " https://stats. oecd.org/glossary/detail.asp?ID=2312.

Polanyi, Michael. The Tacit Dimension. Garden City, NY: Doubleday, 1966.

Ramos, Arthur. "Acculturation among the Brazilian Negroes." The Journal of Negro History 26, no. 2 (1941): 244-50.

Rodgers, Paul A., Graham Green, and Alistair McGown. "Using Concept Sketches to Track Design Progress." Design Studies 21 (2000): 451-64.

Rosenberg, Terry E. "New Beginnings and Monstrous Births: Notes Towards an Appreciation of Ideational Drawing." (2008).

Schön, Donald. The Reflexive Practitioner: How Professionals Think in Action. New York, NY: Basic, 1983. Schwartz, Fred R. "Graduate Education in the Fine Arts." Art Education 25, no. 7 (1972): 20-22.

Scrivener, Stephen. "The Art Object Does Not Embody a Form of Knowledge." England: University of Hertfordshire, 2002.

Scrivener, Stephen. "Characterising Creative-Production Doctoral Projects in Art and Design." International Journal of Design Sciences and Technology 10, no. 2 (2002): 25-43.

Sela-Smith, Sandy. "Heuristic Research: A Review and Critique of Moustakas's Method." Journal of Huma-
Ings, Welby. "Managing Heuristics as a Method of Inquiry in Autobiographical Graphic Design Theses." (2011).

Jones, Timothy Emlyn. "The PhD in Art \& Design." Paper presented at the ELIA Comhar Conference, Dublin, 2002.

Klein, Julian. "What Is Artistic Research?”. Gegenworte - Berlin-Brandenburgische Akademie der Wissenschaften 23 (2010): 1-6.

Kleining, Gerhard, and Harald Witt. "The Qualitative Heuristic Approach: A Methodology for Discovery in Psychology and the Social Sciences. Rediscovering the Method of Introspection as an Example." 113 (2000).

Mäkelä, Maarit. "Knowing through Making: The Role of the Artefact in Practice-Led Research." Know Techn Pol 20 (2007): 157-63.

Moustakas, Clark. Heuristic Research: Design, Methodology, and Applications. Thousand Oaks, CA: SAGE, 1990. doi:10.4135/9781412995641.

Mühl, Sebastian. "Artistic Research as a Challenge for Art Criticism." Notebook for art, theory and related zones 20 (2016): 1-13. http://vvp.avu.cz/wp-content/ uploads/2016/12/muhl.pdf.

OECD. Frascati Manual 2015: Guidelines for Collecting and Reporting Data on Research and Experimental Development. Paris: OECD Publishing, 2015.

OECD. "Glossary of Statistical Terms " https://stats. oecd.org/glossary/detail.asp?ID=2312.

Polanyi, Michael. The Tacit Dimension. Garden City, NY: Doubleday, 1966.

Ramos, Arthur. "Acculturation among the Brazilian Negroes." The Journal of Negro History 26, no. 2 (1941): 244-50.

Rodgers, Paul A., Graham Green, and Alistair McGown. "Using Concept Sketches to Track Design Progress." Design Studies 21 (2000): 451-64.

Rosenberg, Terry E. "New Beginnings and Monstrous Births: Notes Towards an Appreciation of Ideational Drawing." (2008).

Schön, Donald. The Reflexive Practitioner: How Professionals Think in Action. New York, NY: Basic, 1983. Schwartz, Fred R. "Graduate Education in the Fine Arts." Art Education 25, no. 7 (1972): 20-22.

Scrivener, Stephen. "The Art Object Does Not Embody a Form of Knowledge." England: University of Hertfordshire, 2002. 
nistic Psychology 42, no. 3 (2002): 53-88.

Slemon, Stephen. "Magic Realism as Post-Colonial Discourse." Canadian Literature 116 (1988): 9-24.

Slemon, Stephen. "Magic Realism as Postcolonial Discourse." In Magical Realism: Theory, History, Community, edited by Lois Parkinson Zamora and Wendy B. Faris. United States of America: Duke University Press, (1995): 407-26.

Splinder, William. "Magic Realism: A Typology." Forum for Modern Language 34, no. 1 (1993): 75-85. Stewart, Charles. "Creolization, Hybridity, Syncretism, Mixture." Portuguese Studies, no. 1 (2011): 48. Strand, Dennis. Research in the Creative Arts. Vol. 98: Department of Employment, Education, Training and Youth Affairs Canberra, 1998.

Sullivan, Graeme. Art Practice as Research: Inquiry in Visual Arts. Sage, 2010.

Thomas, Elaine. "Research Training in the Creative and Performing Arts and Design." Lichfield: UK Council for Graduate Education (2001).

Zamora, Lois Parkinson, and Wendy B. Faris. Magical Realism: Theory, History, Community. United States of America: Duke University Press, 1995.
Scrivener, Stephen. "Characterising Creative-Production Doctoral Projects in Art and Design." International Journal of Design Sciences and Technology 10, no. 2 (2002): 25-43.

Sela-Smith, Sandy. "Heuristic Research: A Review and Critique of Moustakas's Method." Journal of Humanistic Psychology 42, no. 3 (2002): 53-88.

Slemon, Stephen. "Magic Realism as Post-Colonial Discourse." Canadian Literature 116 (1988): 9-24.

Slemon, Stephen. "Magic Realism as Postcolonial Discourse." In Magical Realism: Theory, History, Community, edited by Lois Parkinson Zamora and Wendy B. Faris. United States of America: Duke University Press, (1995): 407-26.

Splinder, William. "Magic Realism: A Typology." Forum for Modern Language 34, no. 1 (1993): 75-85.

Stewart, Charles. "Creolization, Hybridity, Syncretism, Mixture." Portuguese Studies, no. 1 (2011): 48.

Strand, Dennis. Research in the Creative Arts. Vol. 98: Department of Employment, Education, Training and Youth Affairs Canberra, 1998.

Sullivan, Graeme. Art Practice as Research: Inquiry in Visual Arts. Sage, 2010.

Thomas, Elaine. "Research Training in the Creative and Performing Arts and Design." Lichfield: UK Council for Graduate Education (2001).

Zamora, Lois Parkinson, and Wendy B. Faris. Magical Realism: Theory, History, Community. United States of America: Duke University Press, 1995. 